\title{
PRIMING AS A STRATEGY TO OVERCOME DETRIMENTAL PH EFFECTS ON CELLS FOR INTERVERTEBRAL DISC REGENERATION
}

\author{
J. Gansau ${ }^{1,2}$ and C.T. Buckley ${ }^{1,2,3,4, *}$ \\ ${ }^{1}$ Trinity Centre for Biomedical Engineering, Trinity Biomedical Sciences Institute, Trinity College Dublin, \\ The University of Dublin, Dublin, Ireland \\ ${ }^{2}$ School of Engineering, Trinity College Dublin, The University of Dublin, Dublin, Ireland \\ ${ }^{3}$ Advanced Materials and Bioengineering Research (AMBER) Centre, Royal College of Surgeons in Ireland \\ and Trinity College Dublin, The University of Dublin, Dublin, Ireland \\ ${ }^{4}$ Department of Anatomy and Regenerative Medicine, Royal College of Surgeons in Ireland, \\ 121/122 St. Stephen's Green Dublin 2, Dublin, Ireland
}

\begin{abstract}
Disc disease is characterised by degeneration of the nucleus pulposus (NP), the central gelatinous tissue of the intervertebral disc (IVD). As degeneration progresses, the microenvironment of the IVD becomes more hostile (i.e. decrease in oxygen, glucose and $\mathrm{pH}$ ), providing a significant challenge for regeneration using cell-based therapies. Tissue engineering strategies such as priming cells or micro tissues with growth factors prior to implantation may overcome some of these issues by providing a pre-formed protective niche composed of extracellular matrix. The present study investigated the effect of priming, using transforming growth factor $\beta 3$ (TGF- $\beta 3$ ), on bone-marrow-derived stem cells (BMSCs) and articular chondrocytes (ACs) cultured at different $\mathrm{pH}$ levels ( $\mathrm{pH} 7.1,6.8$ and 6.5) representative of the in vivo disc microenvironment. Low $\mathrm{pH}$ was found to have a detrimental effect on both cell viability and matrix accumulation, which could be mitigated by priming cells using TGF- $\beta 3$. Investigating the activation of the transmembrane acid-sensing ion channels (ASIC-1 and -3) showed an increased expression of ASIC-1 in BMSCs and ASIC-3 in ACs at lower $\mathrm{pH}$ levels post-priming. Metabolic activity in terms of lactic acid production was also found to be affected significantly by priming, whereas oxygen and glucose consumptions did not change considerably. Overall, the study demonstrated that cells could be equipped to sustain the harsh environment of the IVD and promote accumulation of NP-like matrix through priming. Such an approach may open new avenues to engineer tissues capable of sustaining challenging microenvironments such as those found in the IVD.
\end{abstract}

Keywords: Acid-sensing ion channel, articular chondrocytes, bone-marrow-derived stem cells, hydrogel, metabolism, nucleus pulposus, pre-culture, transforming growth factor $\beta 3$.

*Address for correspondence: Conor T. Buckley, Trinity Centre for Biomedical Engineering, Trinity Biomedical Sciences Institute, Trinity College Dublin, Dublin, Ireland.

Telephone number: +353 18962061 Fax number: +353 16795554 Email: conor.buckley@tcd.ie

Copyright policy: This article is distributed in accordance with Creative Commons Attribution Licence (http://creativecommons.org/licenses/by-sa/4.0/).

\begin{tabular}{|c|c|c|c|}
\hline & List of abbreviations & $\begin{array}{l}\text { FBS } \\
\text { GCR }\end{array}$ & $\begin{array}{l}\text { foetal bovine serum } \\
\text { glucose consumption rate }\end{array}$ \\
\hline $\mathrm{AC}$ & articular chondrocyte & GDF & growth/differentiation factor \\
\hline AmpB & amphotericin B & hg-DMEM & high-glucose Dulbecco's modified \\
\hline ASC & adipose stem cell & & Eagle's medium \\
\hline ASIC & acid-sensing ion channel & IPSC & induced pluripotent stem cell \\
\hline BMP & bone morphogenetic protein & IVD & intervertebral disc \\
\hline BMSC & bone-marrow-derived stem cell & LacA & lactic acid \\
\hline DAPI & 4',6-diamidino-2-phenylindole & lg-DMEM & low-glucose Dulbecco's modified \\
\hline DMMB & dimethylmethylene blue dye & & Eagle's medium \\
\hline & -binding assay & LPR & lactate production rate \\
\hline ECM & extracellular matrix & NP & nucleus pulposus \\
\hline EDTA & ethylenediaminetetraacetic acid & OCR & oxygen consumption rate \\
\hline
\end{tabular}




$\begin{array}{ll}\text { P/S } & \text { penicillin-streptomycin } \\ \text { PBS } & \text { phosphate-buffered saline } \\ \text { SCDM } & \begin{array}{l}\text { supplemented chemically defined } \\ \text { medium }\end{array} \\ \text { SGAG } & \text { sulphated glycosaminoglycan } \\ \text { TGF- } \beta & \text { transforming growth factor } \beta \\ \text { TIMP } & \text { tissue inhibitors of metalloproteinase }\end{array}$

\section{Introduction}

Low-back pain is a common global health burden, with an estimated annual cost of $\$ 500$ billion in the United States (Dieleman et al., 2016; Manchikanti et al., 2014). It is often associated with degenerative disc disease, which is characterised by degeneration of the NP, the central gelatinous tissue of the IVD (Vergroesen et al., 2015). Given its avascular nature, the IVD poses a challenging microenvironment, with low levels of oxygen and glucose, which can exacerbate during IVD degeneration (Buckley et al., 2018). A compounding issue also occurs during ageing, with the cartilage endplates becoming less permeable due to endplate calcification, which impedes the diffusion and nutrient exchange between the vertebral marrow and the disc itself (Grunhagen et al., 2011). This results in a more hostile microenvironment due to limited nutrient transport, such as oxygen and glucose, as well as accumulation of metabolic by-products, such as LacA. This change in microenvironment results in increased acidity within the IVD, with values as low as 5.7-6.8 (severe to mild degenerated disc) (Diamant et al., 1968; Nachemson, 1969), which affects cellular gene expression, proliferation and cell viability (Naqvi and Buckley, 2016; Razaq et al., 2003; Wuertz et al., 2009), leading to an imbalance in matrix anabolism and catabolism.

Acidic microenvironments affect cells through different intracellular pathways. Transmembrane ASICs are proton-gated sensitive channels and are expressed in various cell types, including ACs and NP cells (Gilbert et al., 2016; Rong et al., 2012; Zhou et al., 2015). Both ASIC-1 and ASIC-3 subunits are expressed in NP cells and ACs, which are permeable to $\mathrm{Na}^{+}$and $\mathrm{Ca}^{2+}$ ions (Cuesta et al., 2014; Zhou et al., 2015). When activated, the influx of ions triggers iondependent proteases, which can alter gene expression and induce cell apoptosis (Yuan et al., 2016).

In the context of administration of cell-based therapies for disc regeneration, it is important to consider the microenvironment and ability of transplanted cells to function normally. Various cell types such as disc-derived cells (AF and NP cells), BMSCs and chondrocytes have been investigated for disc regeneration (Gorensek et al., 2004; IllienJunger et al., 2012). Commercial entities including DiscGenics Inc. (Salt Lake City, UT, USA) and Mesoblast Ltd. (Melbourne, Australia) are also developing allogeneic-based products using NP cells and stem cells, respectively, and are advancing with clinical trials. ISTO Technologies $\left(\mathrm{NuQu}^{\circledR}\right.$, St.
Louis, MO, USA) previously explored the use of juvenile ACs combined with a fibrin carrier for disc repair; however, a phase II study was terminated for undisclosed reasons and the company has indicated a change in direction in their product portfolio (Smith et al., 2018).

The harvesting and use of disc cells for cellbased therapeutics remains a challenge. Firstly, the isolation of disc cells from healthy tissue bears the risk of inducing disc degeneration and raises ethical concerns. Cells isolated from degenerated discs or herniated tissue during surgical procedures appear to be compromised, with a decreased collagen type II accumulation capacity and an increased rate of senescence (Park et al., 2001; Roberts et al., 2006). Moreover, disc cells have limited expansion capacities and limited reproducibility due to mixed populations (Liebscher et al., 2011; Park et al., 2001; Roberts et al., 2006), which has motivated the use of alternative cell types such as stem cells or cartilage-derived cells. Both cell types are more easily accessible, have good in vitro expansion ability and deposit matrix similarly to the NP tissue (Malonzo et al., 2015; Roughley, 2004). Moreover, the impact of the harsh microenvironment of the degenerated IVD is an important factor that may influence the success of these cell therapy approaches. Injected cells may experience limited nutrition or low $\mathrm{pH}$ conditions, resulting in compromised outcomes of the therapy. A further concern relates to the cell metabolism and whether the degenerated microenvironment can sustain increased metabolic demands upon delivery of cells to the targeted site.

Ideally, the injected cells should be capable of sustaining the acidic microenvironment of the disc as well as having a slow metabolic rate to avoid exacerbating nutrient deprivation effects. One approach to improve viability in low $\mathrm{pH}$ microenvironments may be through tissue engineering of a protective ECM niche around the cells, by priming with growth factors (Naqvi et al., 2018; Zhang et al., 2011). In carcinogenic tissue, the pericellular matrix increases drug resistance, indicating its protective features for cancerous cells (Noguera et al., 2012). For IVD regeneration, proposed growth factors to induce differentiation of stem cells towards a disc-like phenotype include GDF-5, GDF-6, BMP-2 and TGF- $\beta 1$ (Bach et al., 2017; Clarke et al., 2014; Colombier et al., 2016; Gantenbein-Ritter et al., 2011; Stoyanov et al., 2011). These cytokines have demonstrated enhanced matrix deposition capacities in both BMSCs and ACs (Coleman et al., 2013; Colombier et al., 2016; Gantenbein-Ritter et al., 2011; Murphy et al., 2015; Stoyanov et al., 2011) and enhanced expression of NP-cell-specific markers, indicating successful differentiation towards an NP-cell phenotype (Clarke et al., 2014). However, culture conditions vary in different studies and do not simulate the harsh IVD-like microenvironment (i.e. low oxygen and low glucose levels). Mueller et al. (2010) observed a slight benefit 
using TGF- $\beta 3$ instead of TGF- $\beta 1$ within the first $14 \mathrm{~d}$ of chondrogenesis; however, the culture conditions were also not representative of the IVD. Previous studies have demonstrated that priming of BMSCs using TGF- $\beta 3$ promotes higher levels of sGAG and collagen deposition and supports cell survival of cryopreserved cells (Naqvi and Buckley, 2015a; Naqvi et al., 2018), which motivated the use of TGF- $\beta 3$ in the present study. Primed or pre-differentiated MSCs have been proposed in several other investigations for cartilage, bone and IVD regeneration (Grayson et al., 2010; Lam et al., 2014; Naqvi et al., 2019; Noth et al., 2007), making this strategy a promising approach to overcome microenvironmental challenges for disc repair.

The overall objective of the study was to explore the effects of acidic microenvironments on BMSCs and ACs and to determine if priming could enhance cellular response in low $\mathrm{pH}$ conditions in terms of viability, metabolism and disc-like matrix accumulation.

\section{Material and Methods}

\section{Ethics statement}

Porcine tissue (NP, bone marrow and articular cartilage) was obtained from a local abattoir and did not require ethical approval.

\section{Experimental design}

The study investigated the effect of matrix acidity on BMSCs and ACs non-primed and primed using TGF- $\beta 3$ in an alginate-bead culture (Fig. 1). Cells were exposed to i) various acid culture conditions ( $\mathrm{pH} 7.1,6.8$ and 6.5) for 3 weeks (non-primed) or ii) standard $\mathrm{pH} 7.4$ with growth factor supplementation for 2 weeks prior to an additional 3 weeks acidic culture conditions (primed). Preliminary studies were also performed in which BMSCs (with and without TGF- $\beta 3$ ) and NP cells (without TGF- $\beta 3$ ) were pre-cultured for 2 weeks prior to exposure to $\mathrm{pH} 6.8$ (low $\mathrm{pH}$ ). All groups were maintained at $5.5 \mathrm{mmol} / \mathrm{L}$ glucose and $5 \%$ oxygen for the duration of the experiment.

\section{Cell isolation and monolayer expansion}

Porcine NP cells were harvested from the lumbar region of porcine donor spines (3-4 months, $20-30 \mathrm{~kg}$ ) within $3 \mathrm{~h}$ of sacrifice. NP tissue was enzymatically digested in $2.5 \mathrm{mg} / \mathrm{mL}$ pronase solution for $1 \mathrm{~h}$ followed by $2 \mathrm{~h}$ in $0.5 \mathrm{mg} / \mathrm{mL}$ collagenase solution at $37^{\circ} \mathrm{C}$ under constant rotation at $10 \mathrm{rpm}$ (Stuart tube rotator). The digest was subjected to agitation cycles at the start and every 30 min thereafter, using a gentleMACS ${ }^{\mathrm{TM}}$ tissue dissociator (Miltenyi Biotech). Digested tissue/cell suspension was passed through a $100 \mu \mathrm{m}$ cell strainer to remove tissue debris followed by $70 \mu \mathrm{m}$ and $40 \mu \mathrm{m}$ cell strainers to separate notochordal cells from the desired NP cells. Then, cells were washed 3 times by repeated centrifugation at $650 \times g$ for $5 \mathrm{~min}$. Cells were seeded at $5 \times 10^{3}$ cells/ $\mathrm{cm}^{2}$ at $37^{\circ} \mathrm{C}$ and $5 \% \mathrm{CO}_{2}$ in a humidified atmosphere in medium consisting of $1 \mathrm{~g}$-DMEM $(1 \mathrm{mg} / \mathrm{mL}$ D-glucose) supplemented with $10 \%$ FBS, $100 \mathrm{U} /$ $\mathrm{mL}$ penicillin, $100 \mu \mathrm{g} / \mathrm{mL}$ streptomycin, $0.25 \mu \mathrm{g} /$ $\mathrm{mL}$ AmpB, 5 ng/mL FGF-2 (PeproTech, UK), and expanded to passage 2 (P2) with medium exchanges performed every $3 \mathrm{~d}$.

Porcine BMSCs were isolated and maintained as previously described (Naqvi and Buckley, 2015a). Briefly, mononuclear cells were isolated from

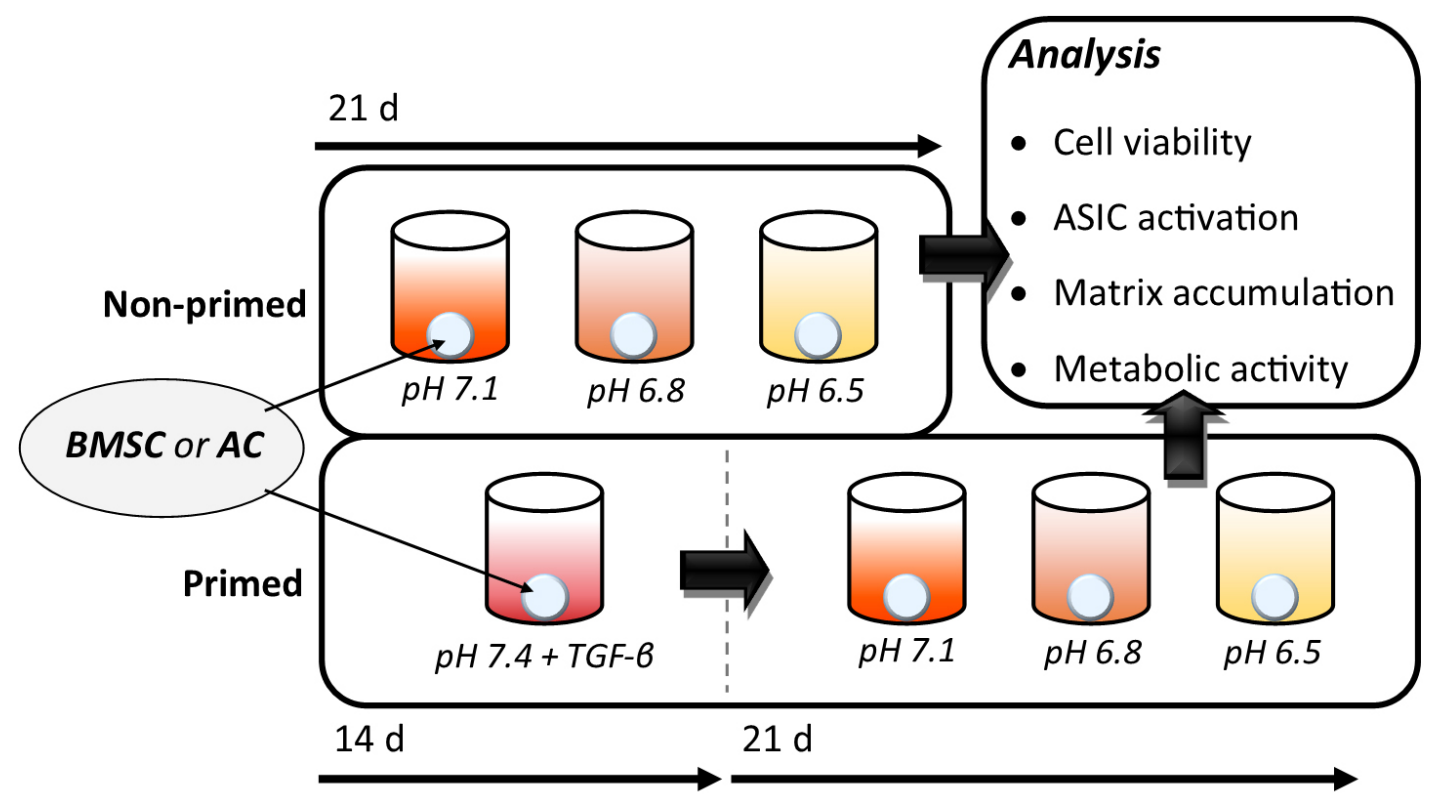

Fig. 1. Study design. Alginate-encapsulated BMSCs and ACs were cultured either in acidic culture conditions ( $\mathrm{pH}$ 7.1, 6.8 and 6.5) without growth factor supplementation for $21 \mathrm{~d}$ (top, non-primed) or for $14 \mathrm{~d}$ with TGF- $\beta 3$ supplementation prior to $21 \mathrm{~d}$ of acidic culture (bottom, primed). Analysis was performed in terms of cell viability, ASIC activation, matrix accumulation and metabolic activity. 
the femora of 3 month-old porcine donors and maintained in hg-DMEM (4.5 mg/mL D-glucose) supplemented with $10 \% \mathrm{FBS}$, penicillin $(100 \mathrm{U} / \mathrm{mL})$, streptomycin $(100 \mu \mathrm{g} / \mathrm{mL})$ (all GIBCO) and AmpB $(0.25 \mu \mathrm{g} / \mathrm{mL}$, Sigma-Aldrich). Cells were washed with PBS after $72 \mathrm{~h}$. When passaged, BMSCs were plated at $5 \times 10^{3} \mathrm{cells} / \mathrm{cm}^{2}$ and expanded to P2 in a humidified atmosphere at $37^{\circ} \mathrm{C}$ and $5 \% \mathrm{CO}_{2}$.

Porcine ACs were isolated from donor-matching articular cartilage. Tissue was finely minced and digested at $37^{\circ} \mathrm{C}$ for $\sim 2.5 \mathrm{~h}$ under constant rotation at $10 \mathrm{rpm}$ (Stuart tube rotator) using collagenase type II (3,000 U/mL, Gibco) in serum-free hg-DMEM containing P/S and AmpB $(0.25 \mu \mathrm{g} / \mathrm{mL})$. The digest was subjected to agitation cycles every $30 \mathrm{~min}$, using a gentleMACS ${ }^{\mathrm{TM}}$ tissue dissociator (Miltenyi Biotech). Using a $100 \mu \mathrm{m}$ cell strainer, debris was removed from the tissue/cell suspension. Cells were seeded at $5 \times 10^{3}$ cells $/ \mathrm{cm}^{2}$ at $37^{\circ} \mathrm{C}$ and $5 \% \mathrm{CO}_{2}$ in medium consisting of lg-DMEM (1 mg/mL D-glucose) supplemented with $10 \% \mathrm{FBS}, \mathrm{P} / \mathrm{S}$ and $\mathrm{AmpB}(0.25 \mu \mathrm{g} /$ $\mathrm{mL}$ ) and cultured until P1.

\section{pH stabilisation}

Media with 3 different $\mathrm{pH}$ values were prepared by adding an appropriate amount of $\mathrm{LacA}$ and $\mathrm{HCl}$ to supplemented lg-DMEM (1 mg/mL D-glucose, 308$340 \mathrm{mOs} / \mathrm{kg}$ ). Briefly, LacA was added to the media to obtain physiological levels $(4 \mathrm{mmol} / \mathrm{L})$ normally found in the IVD (Bartels et al., 1998). Additionally, different amounts of $3 \mathrm{~mol} / \mathrm{L} \mathrm{HCl}$ were added to adjust $\mathrm{pH}$ levels representative of different stages of degenerated disc conditions (i.e. $\mathrm{pH} 7.1,6.8$ and 6.5). The desired $\mathrm{pH}$ values were obtained after $24 \mathrm{~h}$ equilibration in a humidified incubator $\left(\mathrm{CO}_{2}^{-}\right.$ dependent) and were maintained for up to $72 \mathrm{~h}$.

\section{Alginate encapsulation and culture}

Culture-expanded cells were encapsulated in $1.5 \%$ alginate (w/v in PBS) (Pronova UP LVG, FMC NovaMatrix, Sandvika, Norway) at a density of $4 \times 10^{6}$ cells $/ \mathrm{mL}$. The alginate/cell suspension was passed through a $12 \mathrm{G}$ needle and ionically crosslinked for $15 \mathrm{~min}$ using $100 \mathrm{mmol} / \mathrm{L} \mathrm{CaCl}_{2}$ ( $\mathrm{pH}$ 7.2). For the primed group ( $\mathrm{pH} 7.4)$, alginate beads were maintained in $\mathrm{pH}$-adjusted SCDM, consisting of lg-DMEM, $\mathrm{P} / \mathrm{S}, 1 \times$ insulin-transferrinselenium (all from GIBCO), $0.25 \mu \mathrm{g} / \mathrm{mL} \mathrm{AmpB}, 40 \mu \mathrm{g} /$ $\mathrm{mL}$ L-proline, $1.5 \mathrm{mg} / \mathrm{mL}$ bovine serum albumin, $4.7 \mu \mathrm{g} / \mathrm{mL}$ linoleic acid, $50 \mu \mathrm{g} / \mathrm{mL}$ L-ascorbic acid-2phosphate, $100 \mathrm{nmol} / \mathrm{L}$ dexamethasone (all SigmaAldrich) and $10 \mathrm{ng} / \mathrm{mL}$ TGF- 33 (PeproTech). Alginate beads were cultured in standard 24-well plates with one bead per well and $2 \mathrm{~mL}$ of supplemented medium in $5 \%$ oxygen conditions with complete medium exchanges performed twice weekly. The $\mathrm{pH}$ value of acidic media was measured at each change, with no significant changes observed within that time period. Oxygen and glucose levels were chosen to replicate the native conditions within the IVD.

\section{Live/dead assay}

Cell viability was assessed using the LIVE/DEAD ${ }^{\circledR}$ Viability/Cytotoxicity assay kit (Invitrogen). Constructs were removed from culture, cut in half and incubated for $1 \mathrm{~h}$ at $37^{\circ} \mathrm{C}$ in phenol-free lgDMEM medium containing $2 \mu \mathrm{mol} / \mathrm{L}$ calcein-AM and $4 \mu \mathrm{mol} / \mathrm{L}$ ethidium homodimer-1 (Cambridge Bioscience, Cambridge, UK). Following incubation, constructs were imaged using a Leica SP8 scanning confocal microscope at 515 and $615 \mathrm{~nm}$ and analysed using Leica Application Suite X (LAS X) Software.

\section{Biochemical analysis}

Samples were digested with papain $(125 \mu \mathrm{g} / \mathrm{mL})$ in $0.1 \mathrm{~mol} / \mathrm{L}$ sodium acetate, $5 \mathrm{mmol} / \mathrm{L} \mathrm{L}$-cysteine $\mathrm{HCl}$, $0.05 \mathrm{~mol} / \mathrm{L}$ EDTA and $55 \mathrm{mmol} / \mathrm{L}$ sodium citrate (Sigma-Aldrich) at $60{ }^{\circ} \mathrm{C}$ for $18 \mathrm{~h}$ followed by an additional incubation for $1 \mathrm{~h}$ with $1 \mathrm{~mol} / \mathrm{L}$ sodium citrate under constant agitation to disrupt the alginatecalcium crosslinks. DNA content of each sample was quantified using the Hoechst Bisbenzimide 33258 dye assay, using a calf thymus DNA as standard. Proteoglycan content was estimated by quantifying the amount of sGAG in alginate beads using the DMMB assay (Blyscan, Biocolor Ltd., Carrickfergus, Northern Ireland, UK), with a chondroitin sulphate standard. Total collagen content was determined by measuring the hydroxyproline content. Samples were hydrolysed at $110{ }^{\circ} \mathrm{C}$ for $18 \mathrm{~h}$ in concentrated $\mathrm{HCl}(38 \%)$ and assayed using a chloramine-T assay (Kafienah and Sims, 2004), using a hydroxyproline to collagen ratio of $1: 7.69$ (Ignat'eva et al., 2007).

Immunohistochemistry and immunofluorescence For evaluation of collagen types I and II, sections were treated for $1 \mathrm{~h}$ in a humidified environment at $37^{\circ} \mathrm{C}$ with peroxidase followed by treatment with chondroitinase $\mathrm{ABC}$ (Sigma-Aldrich). Sections were incubated with goat serum to block non-specific sites and collagen type I (ab90395, $1: 400 ; 1 \mathrm{mg} / \mathrm{mL}$, mouse monoclonal, Abcam) or collagen type II (sc52658, $1: 400 ; 1 \mathrm{mg} / \mathrm{mL}$, mouse monoclonal, Santa Cruz) primary antibodies were applied for $18 \mathrm{~h}$ at $4{ }^{\circ} \mathrm{C}$. The secondary antibody (Goat Anti-Mouse IgG biotin conjugate, $1.5: 200$ for collagen type I and $1: 300$ for collagen type II; $2.1 \mathrm{mg} / \mathrm{mL}$, B7151, SigmaAldrich) was added for $1 \mathrm{~h}$ followed by incubation with ABC reagent (Vectastain PK-400, Vector Labs, Peterborough, UK) for $45 \mathrm{~min}$. Finally, sections were developed using DAB peroxidase (Vector Labs) for $5 \mathrm{~min}$.

For evaluation of ASIC-1 (ACCN2) and ASIC-3, 5 sections per sample for ASIC- 1 and ACIC- 3 were heat-treated in a humidified environment at $37^{\circ} \mathrm{C}$ using a citrate buffer $(10 \mathrm{mmol} / \mathrm{L}$ in distilled water with $0.05 \%$ Tween 20, Sigma-Aldrich) at $\mathrm{pH} 6$ or pronase (32 PUK/mL, Sigma-Aldrich), respectively. All sections were incubated with goat serum to block non-specific sites and anti ACCN2 (ASIC1) $(1: 50 ; 1 \mathrm{mg} / \mathrm{mL}$, ab176203, rabbit monoclonal, 
Abcam) and anti ASIC-3 (1 : 50; 1 mg/mL, ab49333, rabbit monoclonal, Abcam) primary antibodies were applied for $18 \mathrm{~h}$ at $4{ }^{\circ} \mathrm{C}$. The secondary antibody (ab15007, Goat Anti-Rabbit IgG H\&L Alexa Fluor 488, 1 : 1,000; $2.1 \mathrm{mg} / \mathrm{mL}$, Abcam) was added for $1 \mathrm{~h}$ followed by incubation with DAPI (Vectastain PK400, Vector Labs, Peterborough, UK) for $10 \mathrm{~min} .10$ images per section were taken for image analysis.

Using ImageJ software, the raw integrated density (RawIntDen) of 10 cells per section was quantified and the background intensity by area subtracted to gain the corrected total cell fluorescence value.

\section{Histology}

At each time point, samples were fixed in $4 \%$ paraformaldehyde overnight, dehydrated in a graded series of ethanol, embedded in paraffin wax, sectioned at $6 \mu \mathrm{m}$ and affixed to microscope slides. The sections were stained with alcian blue/aldehyde fuchsin (30 min at room temperature) to assess sGAG content and picrosirius red ( $1 \mathrm{~h}$ at room temperature) to assess collagen distribution (all Sigma-Aldrich).

\section{Metabolic consumption rates}

Oxygen consumption of non-primed and primed alginate beads was monitored for $3 \mathrm{~d}$ in air-tight glass vials using PreSens SensorVials and the SDR Sensor Dish ${ }^{\circledR}$ Reader system (PreSens Precision
Sensing GmbH, Regensburg, Germany). Lg-SCDM at specific acidity levels without growth factor supplementation was used. Glucose concentrations in medium samples from non-primed and primed groups were quantitatively measured using a glucose meter (FreeStyle Optimum, abbot Diabetes Care, Donegal, Ireland) (Naqvi and Buckley, 2015b). Lactate content was determined by measuring the reaction of lactate with NAD+ as well as lactate dehydrogenase with L-lactic acid as the standard, as described previously (Heywood et al., 2006). All respiration rates (oxygen, glucose and lactate) were determined by normalising to the number of viable cells at each time point examined.

\section{Statistical analysis}

Statistical analysis was performed using GraphPad Prism (version 8). Three-way ANOVA was used for the analysis of variance with Tukey's multiple comparison tests to compare between groups (nonprimed vs. primed, BMSCs vs. ACs and effect of $\mathrm{pH}$ ). 3 technical replicates samples were analysed for each experimental group from 3 individual experiments with 3 different porcine donors (biological replicates). Numerical and graphical results are displayed as mean \pm standard deviation and significance was accepted at a level of $p<0.05$.
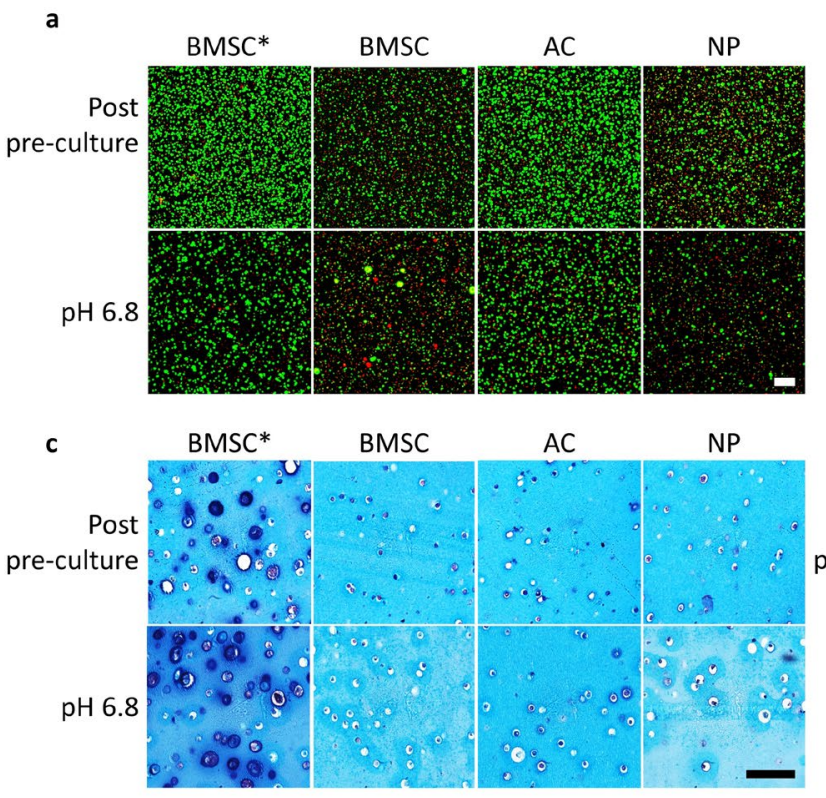

b

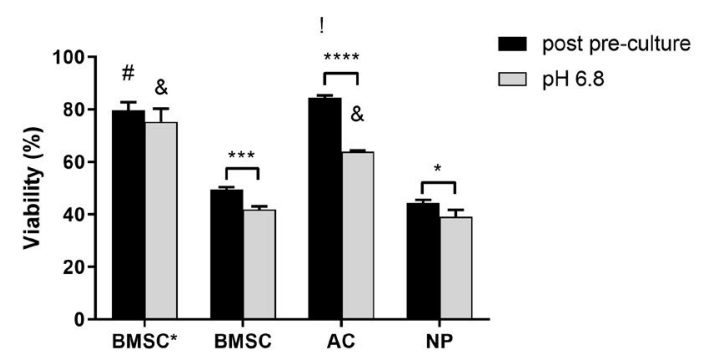

d

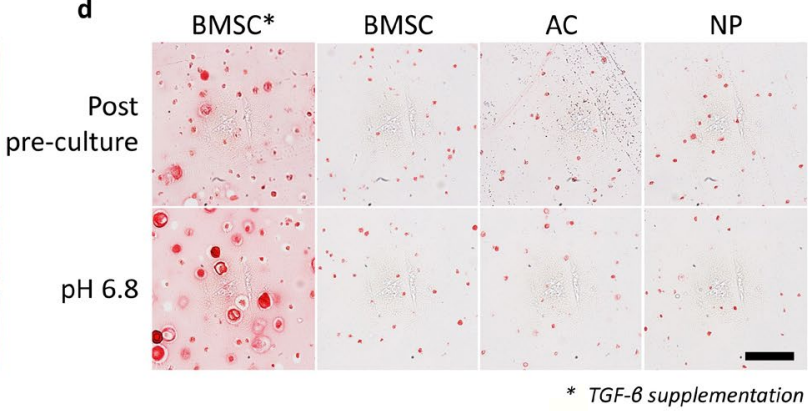

Fig. 2. Comparison of $14 \mathrm{~d}$ pre-culture of BMSCs, ACs and NP cells. (a) Live/dead images of BMSCs with TGF- $\beta 3$ (indicated as BMSC ${ }^{*}$ ) as well as BMSCs, ACs and NP cells, all without TGF- $\beta 3$, after $14 \mathrm{~d}$ pre-culture at pH 7.4 (top) and after an additional culture of $14 \mathrm{~d}$ at pH 6.8 (bottom). (b) Semi-quantitative analysis of cell viability after $14 \mathrm{~d}$ of pre-culture and after additional $14 \mathrm{~d}$ at $\mathrm{pH} 6.8$. \# indicates significant difference between post pre-cultured BMSC* when compared to BMSC and NP, respectively $(p<0.0001)$; \& indicates significant difference between BMSCs and ACs after $\mathrm{pH} 6.8$ culture compared to all other groups $(p<0.0001)$; ! indicates significant difference between ACs post pre-culture when compared to BMSCs and NP cells $(p<0.0001){ }^{*},{ }^{* * *}$ and ${ }^{* * * *}$ indicate significant differences between groups indicated $(p<0.05, p<0.001$ and $p<0.0001$, respectively). (c) Alcian blue/aldehyde fuchsin staining indicating sGAG deposition (dark blue/ purple) and (d) picrosirius red staining indicating total collagen deposition. All scale bars: $150 \mu \mathrm{m}$. 


\section{Results}

Pre-culture without TGF- $\beta 3$ resulted in decreased cell viability and limited matrix accumulation

Preliminary studies were performed in which BMSCs were pre-cultured for 2 weeks without TGF- $\beta 3$ prior to exposure to low $\mathrm{pH}$ at 6.8 for an additional 2 weeks (Fig. 2). Significantly lower cell viability was observed for BMSCs and NP cells cultured for 2 weeks at standard $\mathrm{pH}$ (7.4) without TGF- $\beta 3$, compared to BMSCs with TGF- $\beta 3$ (indicated BMSC ${ }^{*}$ ) and ACs $(p<0.0001)$ (Fig. 2a,b). Moreover, the viability of ACs dropped significantly after low-pH cell culture, despite the preculture at normal $\mathrm{pH}$ for $14 \mathrm{~d}$. In addition, sGAG and collagen deposition was notably limited for cells cultured without TGF- $\beta 3$ (Fig. 2c,d), which motivated the study design to exclude pre-culture without growth factor and NP cells as experimental groups from further investigations.

\section{Priming significantly improved BMSC viability}

Baseline levels at day 0 showed homogeneously distributed viable cells across the construct for BMSCs and ACs, with a viability of $67.7 \%$ and $75.5 \%$, respectively (Fig. 3a,b). Non-primed BMSCs exhibited low cell viability at all $\mathrm{pH}$ levels examined, with average values of $27.3 \%$ and $20.7 \%$ at $\mathrm{pH} 7.1$ and 6.8 , respectively, and a significant drop observed at pH $6.5(2.2 \%)$, compared to $\mathrm{pH} 7.1(p<0.001)$ and $6.8(p<0.01)$ (Fig. 3c,e). ACs, however, appeared to be less sensitive to different $\mathrm{pH}$ conditions, maintaining approximately $62.0 \%$ viability across all $\mathrm{pH}$ levels investigated. After $14 \mathrm{~d}$ of priming using TGF- $\beta 3$, cell viability of both cell types was improved with a significant increase to $76.3 \%$ and $73.5 \%$ for BMSCs at $\mathrm{pH} 7.1$ and 6.8 , respectively $(p<0.0001)$. Notably, BMSCs at $\mathrm{pH} 6.5$ showed a significant increase in cell viability of $62.0 \%$, which is a 28 -fold increase when compared to non-primed conditions (Fig. 3d,e). ACs also demonstrated improved viability of $84.4 \%$, $80.7 \%$ and $73.5 \%$ at $\mathrm{pH} 7.1,6.8$ and 6.5 , respectively. Quantification of total DNA showed a decreased level of DNA over time for non-primed beads compared to day 0 , with consistently lower levels of DNA across all $\mathrm{pH}$ levels and cell types examined. 2 weeks of priming increased the amount of DNA significantly $(p<0.0001)$, which was maintained during culture in low $\mathrm{pH}$ medium for all groups examined (Fig. 3f).

\section{Increased expression of ASIC-1 after priming of BMSCs}

Semi-quantitative image analysis of ASIC expression demonstrated that $\mathrm{pH}$ and priming significantly correlated with ASIC-1 fluorescence signal $(p<0.0001)$, with no significant correlation observed for cell type and ASIC-1 expression ( $p=0.5042)$ (Fig. 4a,b). Multiple analysis revealed significant differences between individual groups, including comparisons between non-primed cells at pH 6.8 $(p<0.001)$, primed cells at $\mathrm{pH} 7.1$ and primed cells at $\mathrm{pH} 6.5$ ( $p<0.0001$ and $p<0.01$, respectively) (Fig. 4b). Expression level of ASIC-3 was also found to be significantly influenced by $\mathrm{pH}$ and priming $(p=0.0015$ and $p=0.0003$, respectively), with no difference based on cell type $(p=0.1003)$ (Fig. 4a,c). However, multiple analysis also showed significant differences between individual groups, including primed cells at $\mathrm{pH} 6.8$ and $6.5(p<0.01$ and $p<0.05$, respectively). Interestingly, ACs formed cell clusters in all acidic levels ( $2-5$ cells per cluster) after priming (Fig. 4a).

\section{Matrix acidity inhibited sGAG accumulation, which could be mitigated by priming}

Increased acidity was found to inhibit sGAG accumulation of non-primed ACs and was particularly pronounced at $\mathrm{pH}$ 6.5. Unsurprisingly, non-primed BMSCs did not accumulate sGAG at any $\mathrm{pH}$ (Fig. 5a). However, after exposure to TGF- $\beta 3$ for $14 \mathrm{~d}$, both BMSCs and ACs accumulated a baseline level of sGAG of $83.8 \pm 49.2 \mu \mathrm{g}$ and $78.8 \pm 15.4 \mu \mathrm{g}$, respectively, which increased 1.6-fold and 1.4-fold for BMSCs at pH 7.1 and 6.8. ACs accumulated an additional $30 \%$ sGAG when compared to post-priming baseline level throughout the low pH exposure (7.1 and 6.8) of 3 weeks (Fig. 5a). No change in sGAG deposition was observed after the $21 \mathrm{~d}$ culture at $\mathrm{pH} 6.5$ for both BMSCs and ACs. Comparing the two different cell types, it was evident that non-primed ACs had a larger sGAG accumulation capacity than BMSCs; however, primed BMSCs produced similar levels across all groups (Fig. 5a,b). Statistical analysis using three-way ANOVA confirmed the significant impact of priming on sGAG deposition $(p<0.0001)$. Histologically, non-primed BMSCs only exhibited background staining for alginate (light blue) but no staining for sGAG (dark blue/purple) and this result was comparable to day 0 histology, which also correlated with the biochemical findings. Nonprimed ACs exhibited pericellular deposition of sGAG at all pH levels, however at pH 6.5, the sGAG level deposited was below the detection limit of the assay (indicated with "nd") but was still visible histologically (Fig. 5c left). Histological images obtained post-priming with TGF- $\beta 3$ (prior to low $\mathrm{pH}$ culture) revealed a significant amount of sGAG deposition for both BMSCs and ACs, as expected. In addition, BMSCs cultured at $\mathrm{pH} 7.1$ and $\mathrm{pH} 6.8$ exhibited intense staining after priming, which correlated with the biochemical quantification (Fig. $5 c$ right).

BMSCs accumulated more collagen, with a larger amount of collagen II deposition

A low level of collagen deposition was observed for both non-primed BMSCs and ACs (Fig. 6). However, similar to the results for sGAG accumulation, an increase in baseline total collagen levels was observed for BMSCs $(71.2 \pm 15.5 \mu \mathrm{g})$ and ACs $(60.0 \pm 13.6 \mu \mathrm{g})$ post-priming (Fig. 6a). For ACs, these levels were maintained at all $\mathrm{pH}$ levels, with no significant changes observed for either total collagen or collagen 


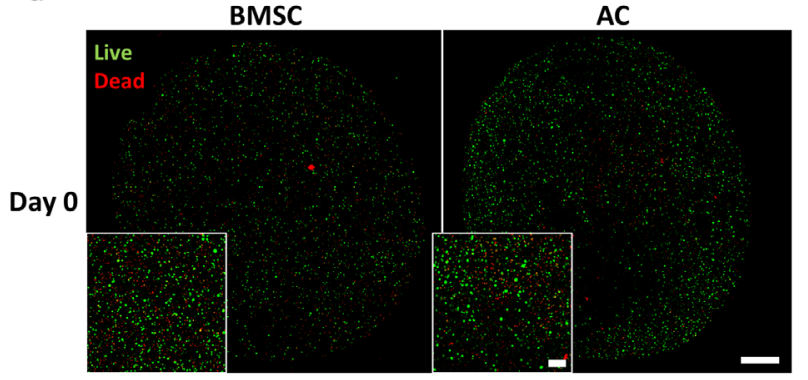

c

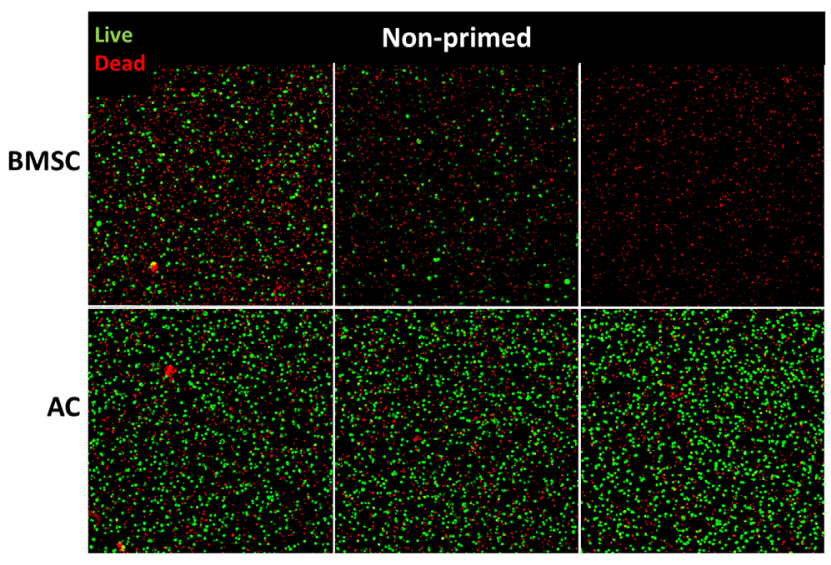

pH 7.1

pH 6.8

e

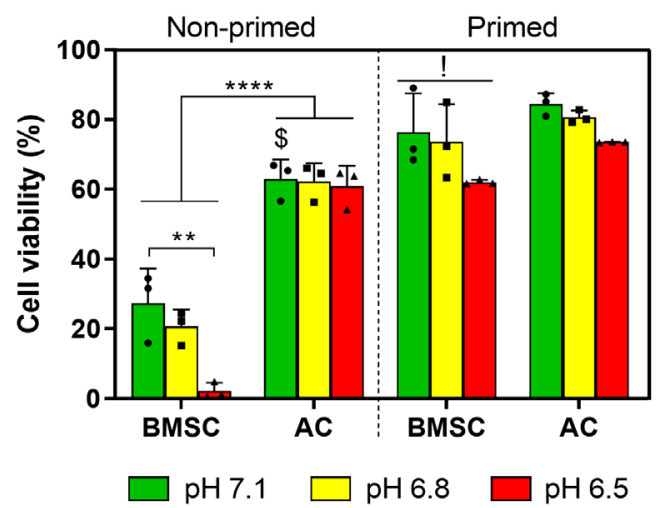

\begin{tabular}{|c|c|c|}
\hline $\begin{array}{c}\text { Source of } \\
\text { variation }\end{array}$ & $p$ value & $\begin{array}{c}p \text { value } \\
\text { summary }\end{array}$ \\
\hline $\mathrm{pH}$ & $<0.0001$ & $* * * *$ \\
\hline Priming & $<0.0001$ & $* * * *$ \\
\hline Cell type & $<0.0001$ & $* * * *$ \\
\hline
\end{tabular}

b

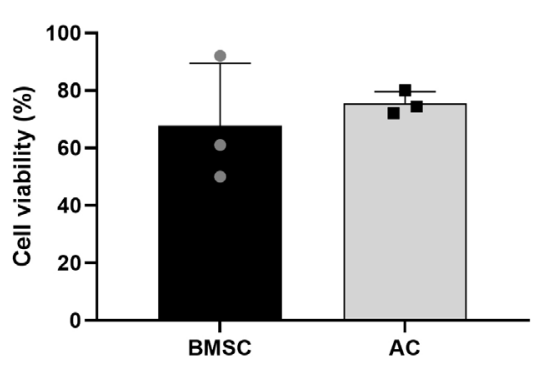

d

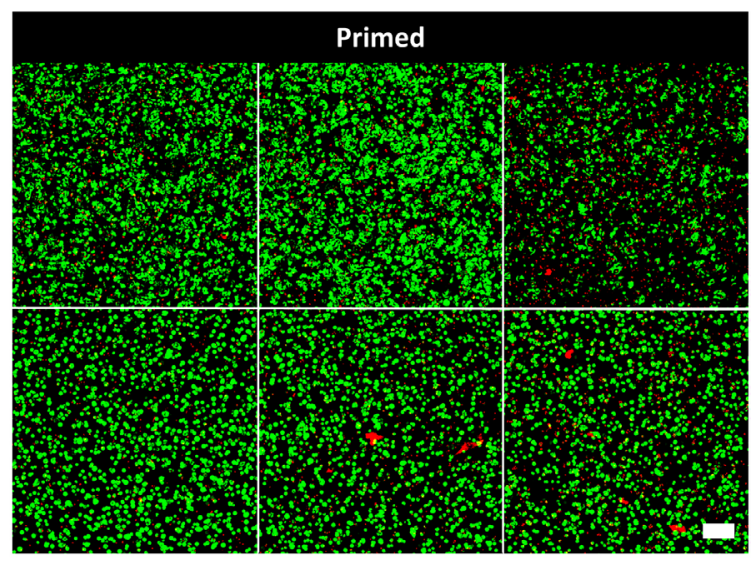

pH 7.1

pH 6.8

pH 6.5

f

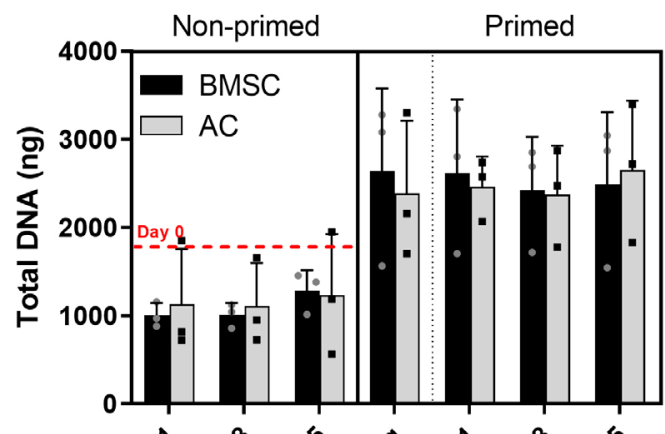

\begin{tabular}{|c|c|c|}
\hline $\begin{array}{l}\text { Source of } \\
\text { variation }\end{array}$ & $p$ value & $\begin{array}{c}p \text { value } \\
\text { summary }\end{array}$ \\
\hline $\mathrm{pH}$ & 0.7341 & ns \\
\hline Priming & $<0.0001$ & $* * * *$ \\
\hline Cell type & 0.9018 & ns \\
\hline
\end{tabular}

Fig. 3. Cell viability and proliferation of BMSCs and ACs. (a) Live/dead images of BMSCs and ACs at day 0 (full construct, scale bar: $0.5 \mathrm{~mm}$ ). (b) Semi-quantitative analysis of cell viability at day 0 . (c) Live/Dead analysis after culture in different $\mathrm{pH}$ conditions without priming and (d) with priming. Scale bar: $150 \mu \mathrm{m}$. (e) Semi-quantitative analysis of cell viability without priming and with priming. ! indicates significant difference between non-primed and primed BMSCs for all pH levels $(p<0.0001)$; \$ indicates significant difference between non-primed and primed ACs at pH $7.1(p<0.05)$; ${ }^{* * *}$ and ${ }^{* *}$ indicate significant difference between specified groups ( $p<0.0001$ and $p<0.01$, respectively). (f) Biochemical quantification of DNA content of non-primed and primed beads. Tables show results of three-way ANOVA of individual parameters on cell viability and total DNA, respectively. $\mathrm{ns}=$ not significant. 
normalised by DNA content (Fig. 6a,b). However, BMSCs showed a 1.5-fold increase in total collagen when cultured for $21 \mathrm{~d}$ at $\mathrm{pH} 7.1$ post-priming (Fig. 6a). This newly synthesised collagen by BMSCs was inhibited with increasing matrix acidity, with a $\mathrm{pH}$ of 6.5 resulting in maintenance of basal levels. Overall, three-way ANOVA revealed a significant impact of priming on total collagen and collagen/ DNA level $(p<0.0001)$ as well as $\mathrm{pH}$ on collagen/ DNA level ( $p=0.0043)$. The choice of cell type was found to be significant for all parameters measured: total collagen $(p=0.0104)$, collagen/DNA $(p=0.0002)$ and sGAG/collagen $(p=0.0032)$. Biochemical results were confirmed histologically, exhibiting intense staining of primed samples prior to low $\mathrm{pH}$ culture and after culture at pH 7.1 and 6.8, indicating a larger deposition of collagen matrix (Fig. 6d).

To evaluate matrix quality, the sGAG/collagen ratio was determined, with an average value of $1.5 \pm 0.4$. A significant correlation was observed for sGAG/collagen ratio for priming and cell type $(p<0.0001$ and $p=0.0032$, respectively) but not $\mathrm{pH}$ level ( $p=0.6509)$ (Fig. 6c). Weak staining for collagen type I was observed for both BMSCs and ACs for all $\mathrm{pH}$ levels after priming. Increased deposition of collagen type II was found in the pericellular region of all AC cultures for all acidic conditions. More intense and obvious collagen type II staining was detected throughout primed BMSC beads cultured at $\mathrm{pH} 7.1$ and 6.8, which was diminished at pH 6.5 (Fig. 6d).

a

pH 7.1

pH 6.8

pH 6.5
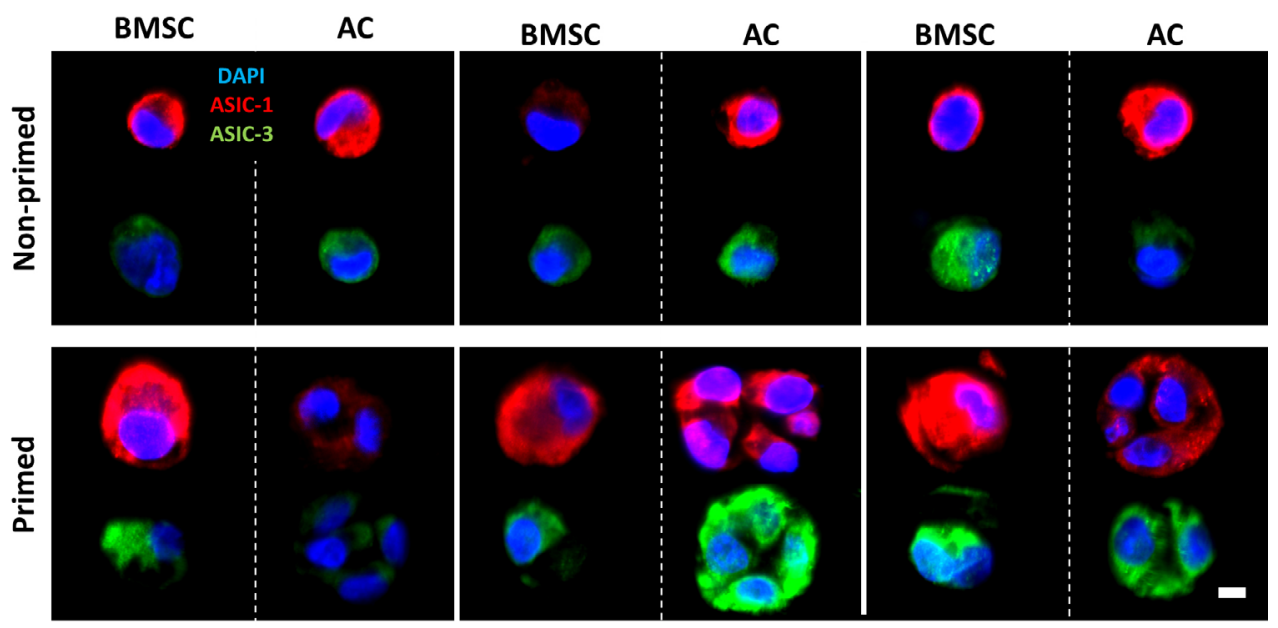

b
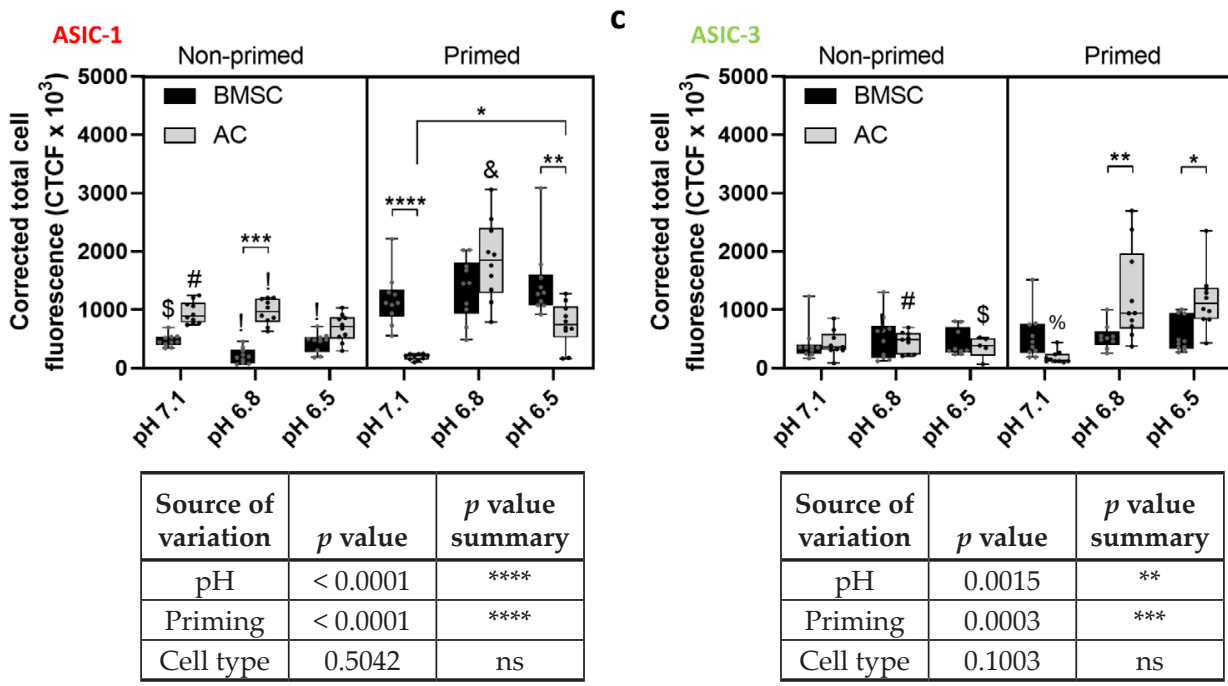

Fig. 4. Expression of ASICs in BMSCs and ACs. (a) Immunofluorescence of ASIC-1 (red) and ASIC-3 (green) of non-primed (top) and primed (bottom) BMSCs and ACs at different pH conditions (scale bar: $5 \mu \mathrm{m}$ ). (b) Semi-quantitative evaluation of the intensity of ASIC-1 expression. \$, \# and ! indicate significant difference between non-priming and priming of respective group $(p<0.01, p<0.001$ and $p<0.0001$, respectively); \& indicates significant difference between primed ACs at $\mathrm{pH} 6.8$ when compared to primed ACs at all other $\mathrm{pH}$ levels $(p<0.0001){ }^{*},{ }^{* *},{ }^{* *}$ and ${ }^{* * * *}$ indicate significant difference between specified groups $(p<0.05$, $p<0.01, p<0.001$ and $p<0.0001$, respectively). (c) Semi-quantitative evaluation of intensity of ASIC-3 expression. \$ and \# indicate significant difference between non-priming and priming of respective group $(p<0.01$ and $p<0.001$, respectively); \% indicates significant difference between primed ACs at $\mathrm{pH} 7.1$ when compared to primed ACs at all other pH levels $(p<0.0001) ;{ }^{*}$ and ${ }^{* *}$ indicate significant difference between specified groups ( $p<0.05$ and $p<0.01$, respectively). Tables show results of three-way ANOVA of individual parameters on fluorescence intensity. ns = not significant. 
Priming altered the lactate production of BMSCs and ACs

OCR of BMSCs was found to be upregulated ( 2-fold) post-priming, whereas OCR of ACs tended to decrease post-priming (Fig. 7a). Overall, the cell type had a significant impact on OCR $(p=0.0099)$. There was a trend towards increased GCRs of BMSCs after priming at all pH levels; however, the differences were not found to be statistically significant. ACs showed a trend towards decreased GCRs with increasing matrix acidity post-priming (Fig. 7b). A similar profile was observed for LPR, with a significant difference between non-primed and primed BMSCs at pH $6.8(p<0.01)$ as well as a trend towards decreasing LPR with increasing acidity in AC medium. Overall, three-way ANOVA revealed a

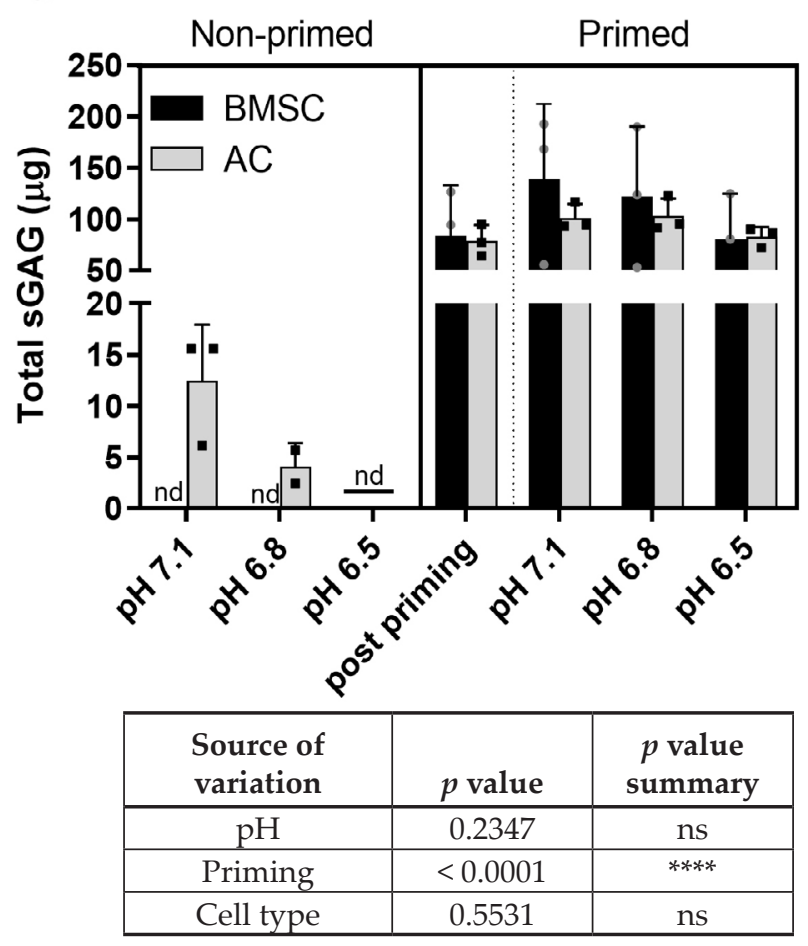

b

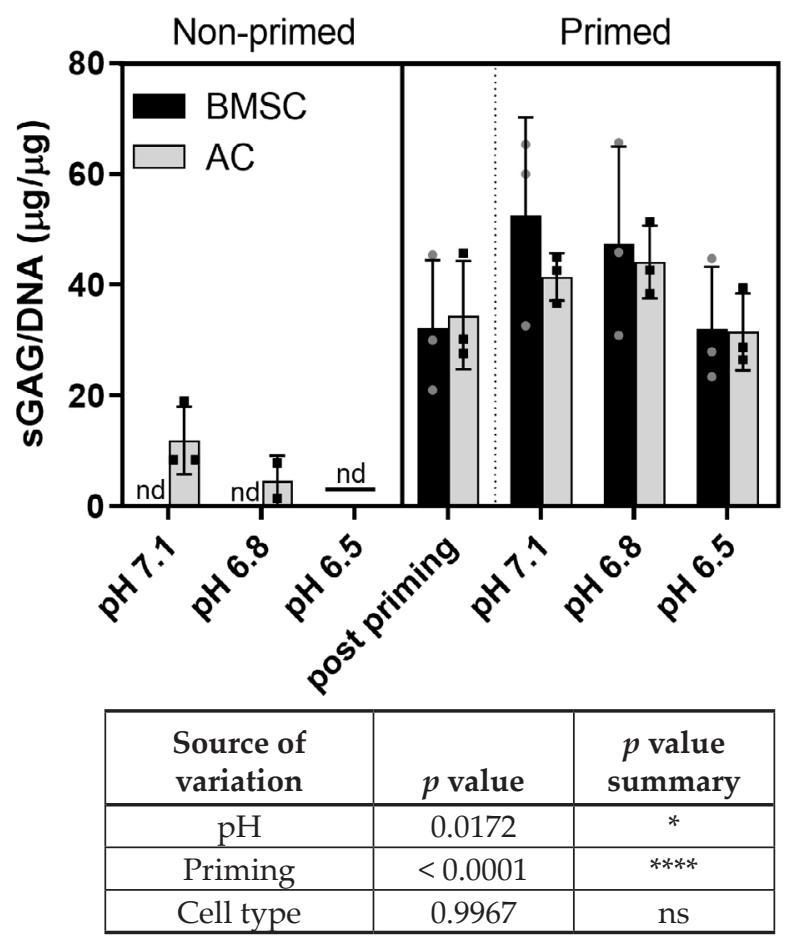

C

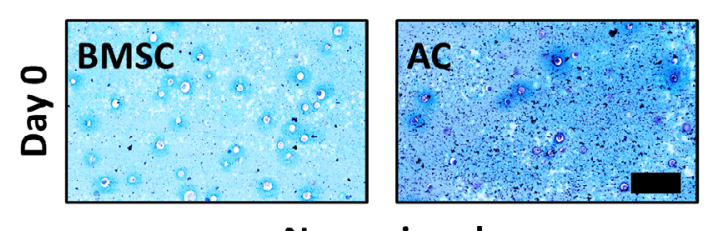

Non-primed

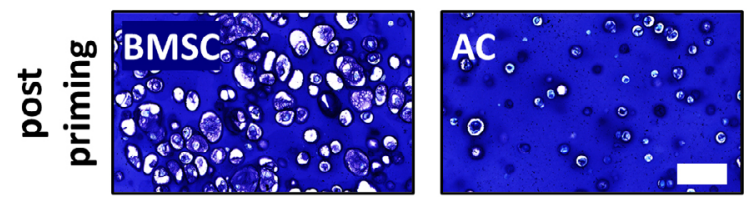

Primed
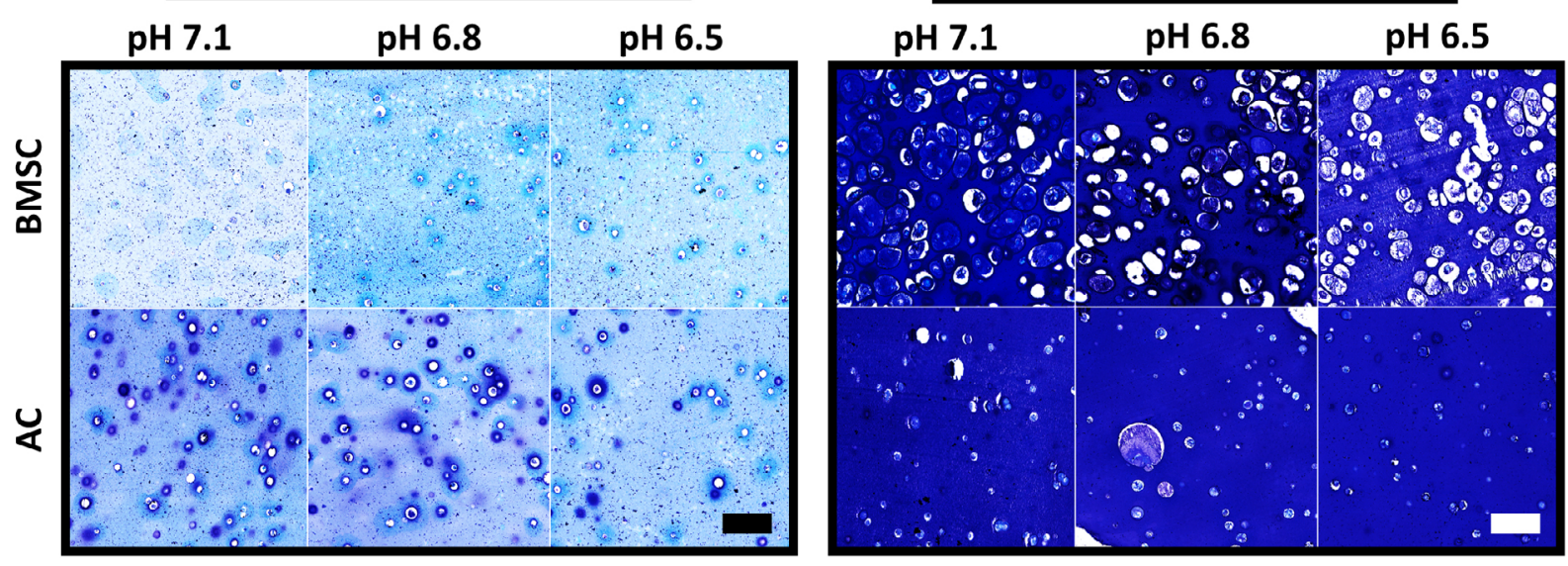

Fig. 5. sGAG accumulation of non-primed and primed BMSCs and ACs at different pH levels. (a) Total sGAG ( $\mu \mathrm{g})$ accumulation of non-primed or primed BMSCs (black bar) and ACs (grey bar) after $21 \mathrm{~d}$ of exposure to low $\mathrm{pH}$ conditions. (b) Normalised sGAG levels to total DNA $(\mu \mathrm{g} / \mu \mathrm{g})$; nd: not-detectable. Tables show results of three-way ANOVA of individual parameters on total sGAG levels and sGAG/DNA ratio, respectively. (c) Alcian blue/aldehyde fuchsin staining indicating sGAG deposition (dark blue/purple) of non-primed/primed cultures before and after low $\mathrm{pH}$ exposure. Scale bars: $100 \mu \mathrm{m}$. ns = not significant. 
a significant correlation between LPR and priming $(p<0.0001)$ as well as $\mathrm{pH}(p=0.0091)$ (Fig. 7c). No significant difference in LPR/GCR was found between individual groups; however, priming showed a significant impact overall ( $p=0.0147$ ) (Fig. 7d).

\section{Discussion}

It is widely believed that disc degeneration originates in the NP of the IVD, which is thought to become more hostile with increasing degeneration due to nutrient transport limitations that can result in higher acidity microenvironments (Bibby et al., 2005b; Huang et al., 2014). If cell therapies are to become widespread as part of disc regeneration strategies, then it is important to ascertain whether transplanted cells can sustain these harsh microenvironments and to develop tissue engineering techniques to enhance cellular responses. The present study explored the effect of these challenging acidic conditions on BMSCs and ACs and investigated if priming could a

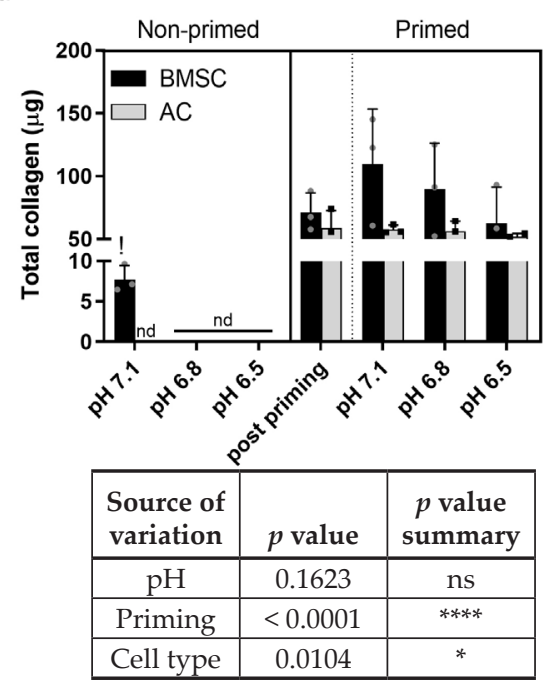

b

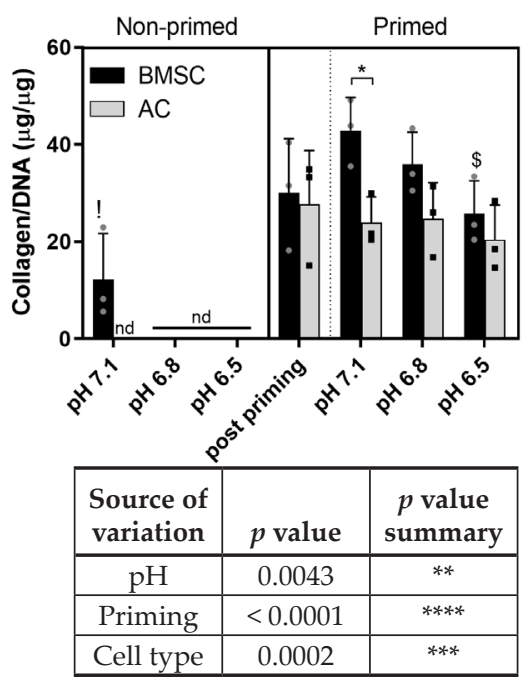

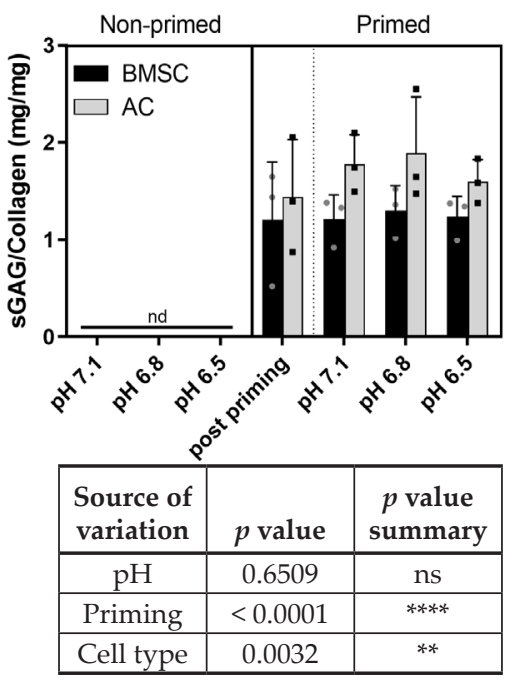

d
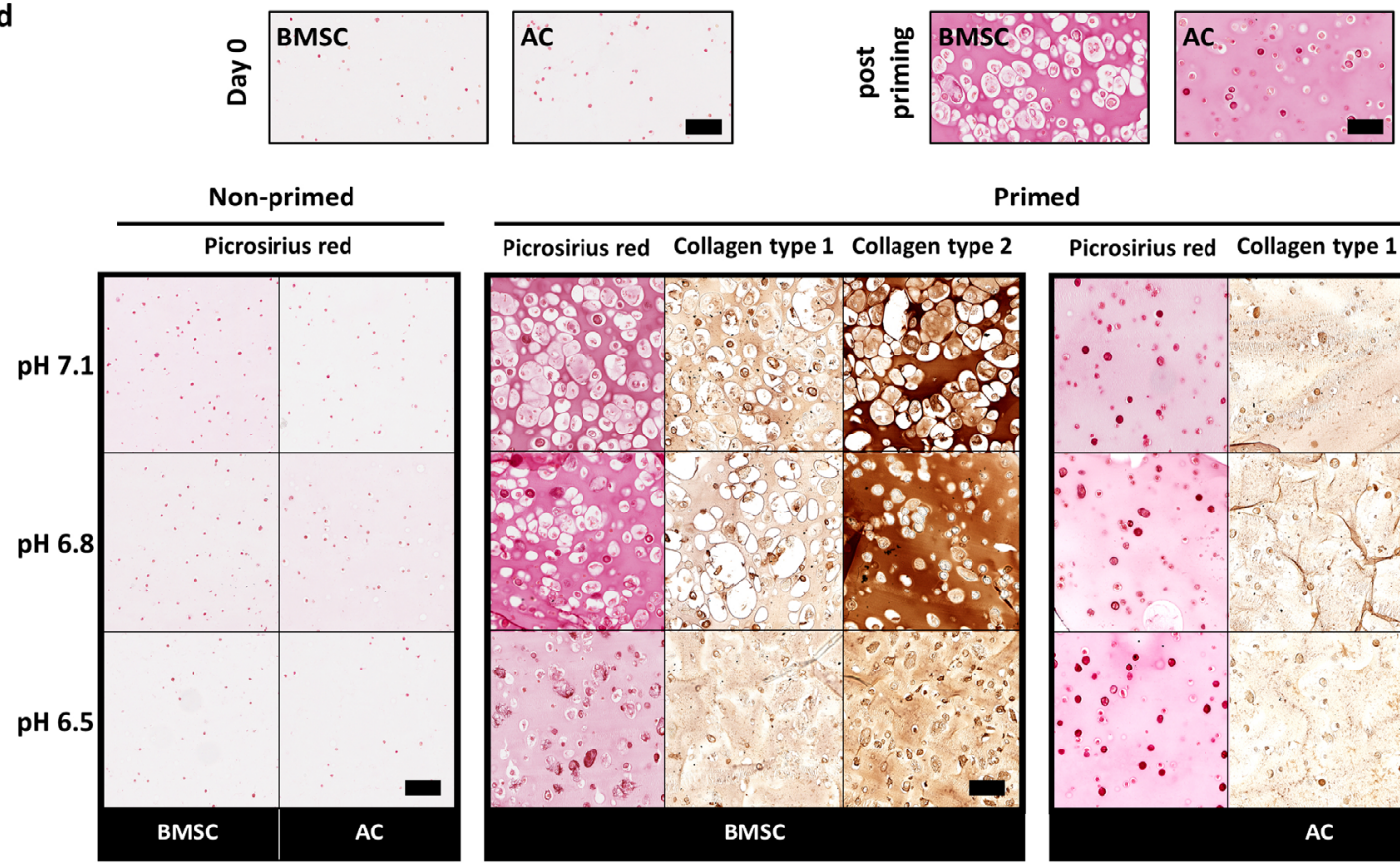

Primed

Picrosirius red Collagen type 1 Collagen type 2

Fig. 6. Collagen accumulation of non-primed and primed BMSCs and ACs at different pH levels. (a) Total collagen deposition $(\mu \mathrm{g})$ of non-primed and primed BMSCs (black bar) and ACs (grey bar) after $21 \mathrm{~d}$. ! indicates significant difference between non-primed and primed samples of indicated group $(p<0.0001)$; nd: not-detectable. (b) Total collagen normalised to total DNA content $(\mu \mathrm{g} / \mu \mathrm{g})$. ! indicates significant difference between non-primed and primed samples of indicated group $(p<0.0001)$; ${ }^{*}$ indicates significant difference between primed BMSCs and ACs at pH $7.1(p<0.05)$; \$ indicates significant difference between primed BMSCs at pH 6.5 to $7.1(p<0.05)$. (c) sGAG to collagen ratio $(\mathrm{mg} / \mathrm{mg})$. (d) Picrosirius red staining was used to visualise total collagen deposition at day 0 , after priming phase and after low $\mathrm{pH}$ exposure. Further determination of the specific collagen types (I and II) was performed using immunohistochemical analysis. Scale bars: $100 \mu \mathrm{m}$. ns = not significant. 
enhance cellular response in terms of viability, disclike matrix accumulation and metabolism. By using TGF- $\beta 3$, the detrimental effects of low $\mathrm{pH}$ on cell viability and matrix accumulation could be overcome, demonstrating the potential of priming as a useful tool for cells that will be exposed to critical acidic conditions similar to those found in the degenerated IVD.

Previous studies have investigated the effects of an acidic $\mathrm{pH}$ on the viability of different cell types, including adipose-derived stem cells (Han et al., 2014), BMSCs (Naqvi and Buckley, 2016; Wuertz et al., 2009), NP mesenchymal stem cells (Han et al., 2014), NP cells (Hodson et al., 2018; Razaq et al., 2003) and ACs (Razaq et al., 2003), demonstrating decreasing viability and limited proliferation with increasing matrix acidity. This correlates with the findings in the non-primed groups of the present study.

a

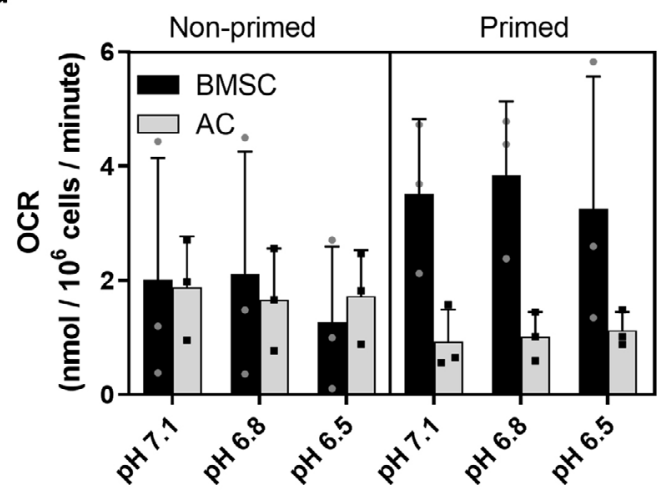

\begin{tabular}{|c|c|c|}
\hline $\begin{array}{c}\text { Source of } \\
\text { variation }\end{array}$ & $\boldsymbol{p}$ value & $\begin{array}{c}\boldsymbol{p} \text { value } \\
\text { summary }\end{array}$ \\
\hline $\mathrm{pH}$ & 0.8418 & $\mathrm{~ns}$ \\
\hline Priming & 0.2785 & $\mathrm{~ns}$ \\
\hline Cell type & 0.0099 & $* *$ \\
\hline
\end{tabular}

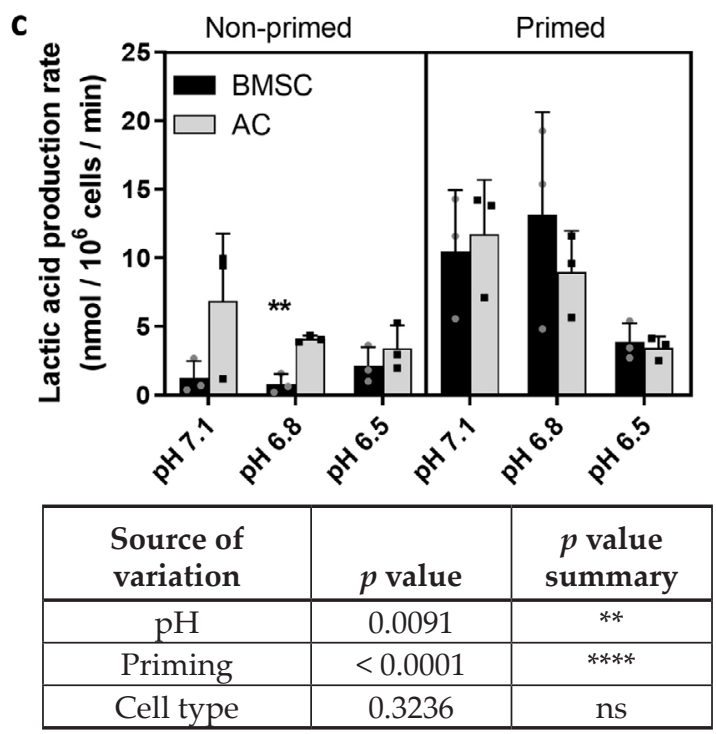

However, none of the previous studies attempted to pre-culture cells to improve their resistance to acidic environments.

Given the significant interest in identifying alternative cell sources for disc repair, the potential benefits of priming BMSCs and ACs prior to acidic microenvironment exposure was examined. BMSCs and ACs are more easily accessible, exhibit better in vitro cell proliferation capacities when compared to disc cells and possess the ability to accumulate NPlike matrix (Le Maitre et al., 2009; Malonzo et al., 2015). Hence, BMSCs and ACs may represent alternative cell sources to disc-derived cells for cell-based repair of the IVD. After an initial preliminary study of pre-culture without TGF- $\beta 3$, lower cell viability and limited matrix deposition was observed when compared to culture with TGF- $\beta 3$. This motivated the exclusion of pre-culture without growth factor

b

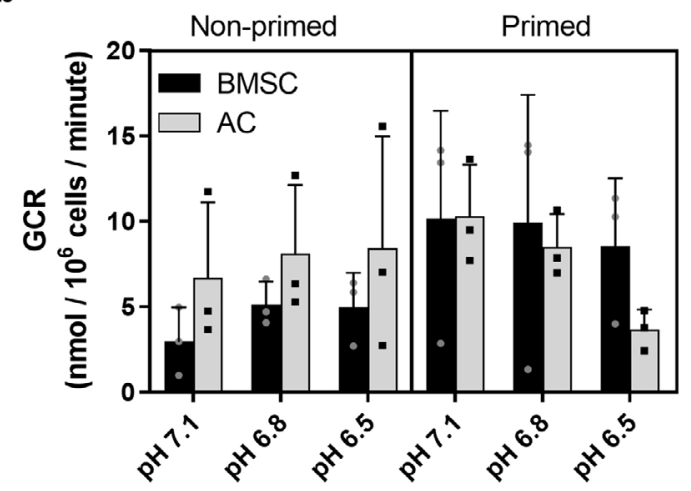

\begin{tabular}{|c|c|c|}
\hline $\begin{array}{c}\text { Source of } \\
\text { variation }\end{array}$ & $\boldsymbol{p}$ value & $\begin{array}{c}\boldsymbol{p} \text { value } \\
\text { summary }\end{array}$ \\
\hline $\mathrm{pH}$ & 0.6632 & $\mathrm{~ns}$ \\
\hline Priming & 0.0939 & $\mathrm{~ns}$ \\
\hline Cell type & 0.6402 & $\mathrm{~ns}$ \\
\hline
\end{tabular}

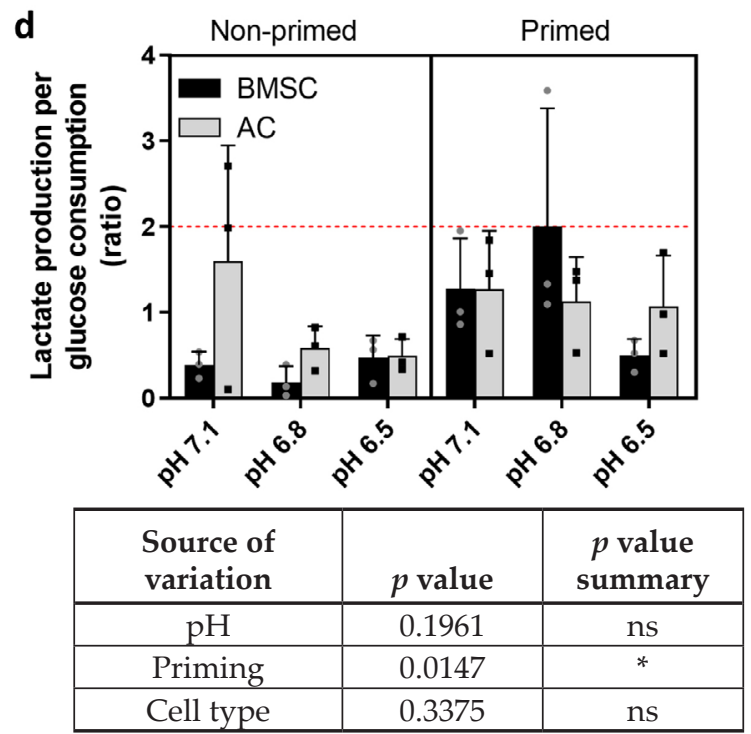

Fig. 7. Metabolic activity of non-primed and primed BMSCs and ACs. (a) OCR, (b) GCR and (c) LPR of BMSCs and ACs at different $\mathrm{pH}$ levels for non-primed (black bar) and primed (grey bar) in nmol/106 cells/ min. ** indicates significant difference between non-primed and primed samples of indicated group $(p<0.01)$. (d) Ratio of produced lactate per consumed glucose of cells either non-primed or primed at different media acidity. Tables show results of three-way ANOVA of individual parameters on metabolic output measures, respectively. ns = not significant. 
supplementation and NP cells from the study. The primed groups using TGF- $\beta 3$ exhibited significantly higher viability after low $\mathrm{pH}$ culture, which may be due to the ECM being produced during the priming phase, providing a protective niche. Interestingly, a similar microenvironment (i.e. low $\mathrm{pH}$, low oxygen) is found in tumours (Riemann et al., 2013; Wei et al., 2020), where cancer cells can dramatically proliferate despite these conditions. Comparing to tumour tissue, it has been reported that $60 \%$ of its mass is ECM, including collagens and proteoglycans (Henke et al., 2019), suggesting a correlation between ECM and cell survival in acidic conditions. The present study demonstrated that non-primed cells accumulated an inadequate amount of ECM molecules when exposed to acidic media. After priming in normal $\mathrm{pH}$ conditions, cells produced a large amount of sGAG, which was maintained after culturing in low $\mathrm{pH}$ media. Moreover, cell viability and proliferation for both primed cell types significantly increased, supporting the hypothesis that sGAG played a key role in the success of the priming strategy. A possible explanation could be a balance between the expression of the TIMPs, which are expressed during the priming phase (Leivonen et al., 2013), and matrix metalloproteinases, which are released during the low pH culture (Gilbert et al., 2016; Han et al., 2014). This would result in maintenance of the pericellular matrix instead of degradation and explains the consistent levels of ECM surrounding primed ACs. In addition, sGAG can act as a proton conductor (Selberg et al., 2019), which may guide free $\mathrm{H}^{+}$ions within the acidic environment around the cells and, therefore, protect cells against direct contact.

In an attempt to better understand the mechanism behind the $\mathrm{pH}$ effect, the expression of ASICs was investigated. ASICs are expressed in various cell types, including neural cells, cancer cells, ACs and disc cells (Gilbert et al., 2016; Yuan et al., 2016; Zhou et al., 2015), where they cause an influx of calcium and sodium ions into the cellular cytoplasm upon activation, which can result in downstream apoptotic effects (Rong et al., 2012). However, in the present study, no such correlation was observed. In contrast, an increase in ASIC-1 expression after priming was found, concomitant with enhanced cell viability.

A previous study using tissue-culture plastic has demonstrated that the expression of this channel results in necrotic changes in rat cells (Zhou et al., 2015), which disagrees with the present findings. However, the different culture technique, $\mathrm{pH}$ environment of 6.0, makes a direct comparison to the 3D alginate culture at $\mathrm{pH}$ between 7.1 and 6.5 (used in the present study) difficult. Additionally, in previous investigations of ASIC expression it has been found that ASIC-1, ASIC-2 and ASIC-3 can also be expressed at neutral $\mathrm{pH}$ (Gautschi et al., 2017; Yu et al., 2010), implying multiple routes by which those channels become transcribed and expressed. This suggested that in the present study a different mechanism enhanced ASIC expression.
Due to a different pathway activation mechanism, different intracellular processes may also be activated subsequently. Calcium, as a second messenger, is not only involved in inflammatory and apoptosis signalling but also in various pathways, regulating cell division, mechanotransduction and actinreorganisation (Berridge et al., 1998; Erickson et al., 2003). Interestingly, a change in AC organisation after priming was observed, which exhibited a cluster formation of 2-5 cells within a lacuna, which is typical for hyaline cartilage. The NP has large amounts of proteoglycans and collagen, predominantly type II, similar to that of the hyaline cartilage tissue. To distinguish these two tissue types, Mwale et al. (2004) investigated differences in matrix composition of both and found that NP tissue contains a much higher sGAG to collagen ratio of $3.5: 1$ in comparison to a low ratio of $0.4: 1$ in hyaline cartilage. In the present study, a high level of collagen type II deposition in primed BMSCs was found, with a sGAG/collagen ratio of $1.5 \pm 0.4: 1$ across all primed groups. This was not as high as native NP tissue but still 3.5-times higher than that of hyaline cartilage, illustrating the potential of priming to enhance NP-like matrix accumulation. Using TGF- $\beta 3$ for priming as a proof-of-principle has shown great improvements in terms of promoting cell viability; however, using a different growth factor such as GDF-5 or a combination may not only enhance cell viability but also further promote cells to deposit more NP-like matrix (Hodgkinson et al., 2019; Le Maitre et al., 2009).

Metabolic activity needs to be considered when proposing cell-based therapies for the IVD, given the limited nutrition available within the disc. In the present study, no significant correlation of priming on OCR or GCR was found by three-way ANOVA. However, the cell type was found to have a significant influence on OCR, highlighting its importance for disc repair. To compare with disc cells, NP cells from a degenerated disc have an OCR of $1.03-1.5 \mathrm{nmol} / 10^{6} \mathrm{cells} / \mathrm{min}$ (Cisewski et al., 2018), which is similar to that of all non-primed samples. The tendency for increased OCR and GCR in primed BMSCs may be dependent on the donor cells and should be considered in terms of clinical translation, as higher rates will inevitably increase the nutrient demands of the implanted cells. Interestingly, priming was found to significantly influence LPR and $\mathrm{pH}$ level. Lactate production is highly influenced by surrounding $\mathrm{pH}$, with decreasing levels at higher acidity (Bibby et al., 2005a). This is in agreement with the present findings for primed cells as well as for non-primed ACs. Moreover, Pattappa et al. (2011) demonstrated increased lactate production by BMSCs during chondrogenic differentiation using TGF- $\beta$ supplementation, which correlates with the results for primed BMSCs in the present study. However, non-primed cells produced lower levels of lactate for both cell types, demonstrating the different metabolic activity of primed and non-primed cells. During anaerobic glycolysis, cells produce approximately 
2 moles of lactate for every mole of glucose consumed (Dashty, 2013), emphasising the challenges of cell nutrition within the IVD. Despite a significant impact of priming on the lactate to glucose ratio $(p<0.05)$, all groups showed a value below 2 , except for primed BMSCs cultured at $\mathrm{pH}$ 6.8, suggesting that cells used aerobic glycolysis and experienced sufficient level of extracellular oxygen within the time period investigated. However, the elevated LPRs may raise concerns in delivering primed cells into the degenerated IVD, which could potentially cause further acidification of the microenvironment and adversely affect the resident disc cells. This could be balanced by reducing the number of primed cells introduced into the disc as part of the cell therapy. In addition, positive effects of co-culturing NP cells with BMSCs have been reported, showing improved matrix deposition capacities of NP cells (Chen et al., 2017; Naqvi and Buckley, 2015a; Naqvi et al., 2019; Richardson et al., 2006), which may improve their resilience towards the decreasing $\mathrm{pH}$ and, therefore, support the strategy of using primed cells for disc repair.

There are several limitations associated with the present study. While cells from porcine donors are found to be similar to human cells, including in vitro expansion capacities, differentiation and immunomodulatory properties (Bosch et al., 2006; Liu et al., 2004; Ringe et al., 2002; Thomson et al., 1993), making them a suitable choice for initial proof-ofprinciple investigations, studies using human cells warrant further investigation to fully appreciate the effectiveness of priming strategies. In addition, while 3D hydrogel systems provide a better representation when compared to standard tissue-culture plastic, they cannot fully recapitulate the complex conditions that exist in vivo. Further studies will be necessary to investigate the effectiveness of priming cells using in vivo models. Moreover, future studies should examine the use of human cells to gain an appreciation of the effectiveness of priming cells for clinical translation. Ideally, for the non-primed group, the cells would be cultured for $14 \mathrm{~d}$ without TGF- $\beta 3$ supplementation, to directly compare ECM synthesis. However, based on the preliminary study, significant cell death and limited matrix accumulation of cells cultured without growth factors at normal $\mathrm{pH}$ were observed. BMSCs do not accumulate key matrix components without some form of growth factor stimulation (i.e. priming) and, therefore, the time period of culture is less of a concern. In addition, other growth factors such as GDF-5, GDF-6, BMP-2 and TGF- $\beta 1$ or combinations thereof should be explored to promote a stable disclike phenotype. In summary, the important aspect of the present study was that it demonstrated the value of priming cells before they were subjected to harsh environments such as acidic $\mathrm{pH}$, as doing so better protects cells in terms of viability. Therefore, priming could be an essential and important step towards successful clinical translation improving cell-based therapy outcomes.

\section{Conclusion}

The results of the present study showed that both BMSCs and ACs were negatively affected by low $\mathrm{pH}$ conditions in terms of cell viability and matrix accumulation, compromising their effectiveness for cell-based repair of tissues, exhibiting a challenging microenvironment. This effect could be overcome by priming using TGF- $\beta 3$ prior to low $\mathrm{pH}$ exposure. Priming was observed to enhance cell viability and provided a baseline level of ECM, offering a protective niche for subsequent matrix accumulation. Therefore, priming could be used as a powerful tissue engineering tool for cell-based regeneration of the IVD to help injected cells withstand its typical harsh microenvironment, facilitate deposition of de novo ECM components and help ameliorate degenerative effects.

\section{Acknowledgements}

This work was supported by Science Foundation Ireland Career Development Award (15/CDA/3476).

\section{References}

Bach FC, Miranda-Bedate A, van Heel FW, Riemers FM, Muller MC, Creemers LB, Ito K, Benz K, Meij BP, Tryfonidou MA (2017) Bone morphogenetic protein-2, but not mesenchymal stromal cells, exert regenerative effects on canine and human nucleus pulposus cells. Tissue Eng Part A 23: 233-242.

Bartels EM, Fairbank JC, Winlove CP, Urban JP (1998) Oxygen and lactate concentrations measured in vivo in the intervertebral discs of patients with scoliosis and back pain. Spine (Phila Pa 1976) 23: 1-28.

Berridge MJ, Bootman MD, Lipp P (1998) Calcium-a life and death signal. Nature 395: 645-648.

Bibby SR, Jones DA, Ripley RM, Urban JP (2005a) Metabolism of the intervertebral disc: effects of low levels of oxygen, glucose, and $\mathrm{pH}$ on rates of energy metabolism of bovine nucleus pulposus cells. Spine (Phila Pa 1976) 30: 487-496.

Bibby SRS, Jones Da, Ripley RM, Urban JPG (2005b) Metabolism of the intervertebral disc: effects of low levels of oxygen, glucose, and $\mathrm{pH}$ on rates of energy metabolism of bovine nucleus pulposus cells. Spine 30: 487-496.

Bosch P, Pratt SL, Stice SL (2006) Isolation, characterization, gene modification, and nuclear reprogramming of porcine mesenchymal stem cells. Biol Reprod 74: 46-57.

Buckley CT, Hoyland JA, Fujii K, Pandit A, Iatridis JC, Grad S (2018) Critical aspects and challenges for intervertebral disc repair and regenerationHarnessing advances in tissue engineering. JOR Spine 1: e1029. DOI: 10.1002/jsp2.1029.

Chen S, Zhao L, Deng X, Shi D, Wu F, Liang H, Huang D, Shao Z (2017) Mesenchymal stem cells 
protect nucleus pulposus cells from compressioninduced apoptosis by inhibiting the mitochondrial pathway. Stem Cells Int 2017: 9843120. DOI: 10.1155/2017/9843120.

Cisewski SE, Wu Y, Damon BJ, Sachs BL, Kern MJ, Yao H (2018) Comparison of oxygen consumption rates of nondegenerate and degenerate human intervertebral disc cells. Spine (Phila Pa 1976) 43: E60-E67.

Clarke LE, McConnell JC, Sherratt MJ, Derby B, Richardson SM, Hoyland JA (2014) Growth differentiation factor 6 and transforming growth factor-beta differentially mediate mesenchymal stem cell differentiation, composition, and micromechanical properties of nucleus pulposus constructs. Arthritis Res Ther 16: R67. DOI: 10.1186/ar4505.

Coleman CM, Vaughan EE, Browe DC, Mooney E, Howard L, Barry F (2013) Growth differentiation factor-5 enhances in vitro mesenchymal stromal cell chondrogenesis and hypertrophy. Stem Cells Dev 22: 1968-1976.

Colombier P, Clouet J, Boyer C, Ruel M, Bonin G, Lesoeur J, Moreau A, Fellah BH, Weiss P, Lescaudron L, Camus A, Guicheux J (2016) TGF-beta1 and GDF5 act synergistically to drive the differentiation of human adipose stromal cells toward nucleus pulposus-like cells. Stem Cell 34: 653-667.

Cuesta A, Del Valle ME, Garcia-Suarez O, Vina E, Cabo R, Vazquez G, Cobo JL, Murcia A, Alvarez-Vega M, Garcia-Cosamalon J, Vega JA (2014) Acid-sensing ion channels in healthy and degenerated human intervertebral disc. Connect Tissue Res 55: 197-204.

Dashty M (2013) A quick look at biochemistry: carbohydrate metabolism. Clin Biochem 46: 13391352.

Diamant B, Karlsson J, Nachemson A (1968) Correlation between lactate levels and $\mathrm{pH}$ in discs of patients with lumbar rhizopathies. Experientia 24: 1195-1196.

Dieleman JL, Baral R, Birger M, Bui AL, Bulchis A, Chapin A, Hamavid H, Horst C, Johnson EK, Joseph J, Lavado R, Lomsadze L, Reynolds A, Squires E, Campbell M, DeCenso B, Dicker D, Flaxman AD, Gabert R, Highfill T, Naghavi M, Nightingale N, Templin T, Tobias MI, Vos T, Murray CJ (2016) US spending on personal health care and public health, 1996-2013. JAMA 316: 2627-2646.

Erickson GR, Northrup DL, Guilak F (2003) Hypo-osmotic stress induces calcium-dependent actin reorganization in articular chondrocytes. Osteoarthritis Cartilage 11: 187-197.

Gantenbein-Ritter B, Benneker LM, Alini M, Grad $S$ (2011) Differential response of human bone marrow stromal cells to either TGF-beta(1) or rhGDF-5. Eur Spine J 20: 962-971.

Gautschi I, van Bemmelen MX, Schild L (2017) Proton and non-proton activation of ASIC channels. PLoS One 12: e0175293. DOI: 10.1371/journal. pone.0175293.

Gilbert HT, Hodson N, Baird P, Richardson SM, Hoyland JA (2016) Acidic pH promotes intervertebral disc degeneration: acid-sensing ion channel -3 as a potential therapeutic target. Sci Rep 6: 37360 . DOI: $10.1038 /$ srep37360.

Gorensek M, Jaksimovic C, Kregar-Velikonja N, Gorensek M, Knezevic M, Jeras M, Pavlovcic V, Cor A (2004) Nucleus pulposus repair with cultured autologous elastic cartilage derived chondrocytes. Cell Mol Biol Let 9: 363-373.

Grayson WL, BhumiratanaS, Grace Chao PH, Hung CT, Vunjak-Novakovic G (2010) Spatial regulation of human mesenchymal stem cell differentiation in engineered osteochondral constructs: effects of pre-differentiation, soluble factors and medium perfusion. Osteoarthritis Cartilage 18: 714-723.

Grunhagen T, Shirazi-Adl A, Fairbank JC, Urban JP (2011) Intervertebral disk nutrition: a review of factors influencing concentrations of nutrients and metabolites. Orthop Clin North Am 42: 465-477.

Han B, Wang HC, Li H, Tao YQ, Liang CZ, Li FC, Chen G, Chen QX (2014) Nucleus pulposus mesenchymal stem cells in acidic conditions mimicking degenerative intervertebral discs give better performance than adipose tissue-derived mesenchymal stem cells. Cells Tissues Organs 199: 342-352.

Henke E, Nandigama R, Ergun S (2019) Extracellular matrix in the tumor microenvironment and its impact on cancer therapy. Front Mol Biosci 6: 160. DOI: $10.3389 /$ fmolb.2019.00160.

Heywood HK, Bader DL, Lee DA (2006) Rate of oxygen consumption by isolated articular chondrocytes is sensitive to medium glucose concentration. J Cell Physiol 206: 402-410.

Hodgkinson T, Shen B, Diwan A, Hoyland JA, Richardson SM (2019) Therapeutic potential of growth differentiation factors in the treatment of degenerative disc diseases. JOR Spine 2: e1045. DOI: 10.1002/jsp2.1045.

Hodson NW, Patel S, Richardson SM, Hoyland JA, Gilbert HTJ (2018) Degenerate intervertebral disc-like $\mathrm{pH}$ induces a catabolic mechanoresponse in human nucleus pulposus cells. JOR Spine 1: e1004. DOI: 10.1002/jsp2.1004.

Huang YC, Urban JP, Luk KD (2014) Intervertebral disc regeneration: do nutrients lead the way? Nat Rev Rheumatol 10: 561-566.

Ignat'eva NY, Danilov N, Averkiev S, Obrezkova M, Lunin V, Sobol, Äô E (2007) Determination of hydroxyproline in tissues and the evaluation of the collagen content of the tissues. J Anal Chem 62: 51-57.

Illien-Junger S, Pattappa G, Peroglio M, Benneker LM, Stoddart MJ, Sakai D, Mochida J, Grad S, Alini M (2012) Homing of mesenchymal stem cells in induced degenerative intervertebral discs in a whole organ culture system. Spine (Phila Pa 1976) 37: 1865-1873.

Kafienah W, Sims TJ (2004) Biochemical methods for the analysis of tissue-engineered cartilage. Methods Mol Biol 238: 217-230.

Lam J, Lu S, Lee EJ, Trachtenberg JE, Meretoja VV, Dahlin RL, van den Beucken JJ, Tabata Y, Wong ME, Jansen JA, Mikos AG, Kasper FK 
(2014) Osteochondral defect repair using bilayered hydrogels encapsulating both chondrogenically and osteogenically pre-differentiated mesenchymal stem cells in a rabbit model. Osteoarthritis Cartilage 22: 1291-1300.

Le Maitre CL, Freemont AJ, Hoyland JA (2009) Expression of cartilage-derived morphogenetic protein in human intervertebral discs and its effect on matrix synthesis in degenerate human nucleus pulposus cells. Arthritis Res Ther 11: R137. DOI: 10.1186/ar2808.

Leivonen SK, Lazaridis K, Decock J, Chantry A, Edwards DR, Kahari VM (2013) TGF-beta-elicited induction of tissue inhibitor of metalloproteinases (TIMP)-3 expression in fibroblasts involves complex interplay between Smad3, p38alpha, and ERK1/2. PLoS One 8: e57474. DOI: 10.1371/journal. pone.0057474.

Liebscher T, Haefeli M, Wuertz K, Nerlich AG, Boos N (2011) Age-related variation in cell density of human lumbar intervertebral disc. Spine (Phila Pa 1976) 36: 153-159.

Liu J, Hu Q, Wang Z, Xu C, Wang X, Gong G, Mansoor A, Lee J, Hou M, Zeng L, Zhang JR, Jerosch-Herold M, Guo T, Bache RJ, Zhang J (2004) Autologous stem cell transplantation for myocardial repair. Am J Physiol Heart Circ Physiol 287: H501-511.

Malonzo C, Chan SC, Kabiri A, Eglin D, Grad S, Bonel HM, Benneker LM, Gantenbein-Ritter B (2015) A papain-induced disc degeneration model for the assessment of thermo-reversible hydrogel-cells therapeutic approach. J Tissue Eng Regen Med 9: E167-176.

Manchikanti L, Singh V, Falco FJ, Benyamin RM, Hirsch JA (2014) Epidemiology of low back pain in adults. Neuromodulation 17 Suppl 2: 3-10.

Mueller MB, Fischer M, Zellner J, Berner A, Dienstknecht T, Prantl L, Kujat R, Nerlich M, Tuan RS, Angele P (2010) Hypertrophy in mesenchymal stem cell chondrogenesis: effect of TGF-beta isoforms and chondrogenic conditioning. Cells Tissues Organs 192: 158-166.

Murphy MK, Huey DJ, Hu JC, Athanasiou KA (2015) TGF-beta1, GDF-5, and BMP-2 stimulation induces chondrogenesis in expanded human articular chondrocytes and marrow-derived stromal cells. Stem Cells 33: 762-773.

MwaleF, Roughley P, Antoniou J (2004) Distinction between the extracellular matrix of the nucleus pulposus and hyaline cartilage: a requisite for tissue engineering of intervertebral disc. Eur Cell Mater 8: 58-63.

Nachemson A (1969) Intradiscal measurements of $\mathrm{pH}$ in patients with lumbar rhizopathies. Acta Orthop Scand 40: 23-42.

Naqvi SM, Buckley CT (2015a) Differential response of encapsulated nucleus pulposus and bone marrow stem cells in isolation and coculture in alginate and chitosan hydrogels. Tissue Eng Part A 21: 288-299.
Naqvi SM, Buckley CT (2015b) Extracellular matrix production by nucleus pulposus and bone marrow stem cells in response to altered oxygen and glucose microenvironments. J Anat 227: 757-766.

Naqvi SM, Buckley CT (2016) Bone marrow stem cells in response to intervertebral disc-like matrix acidity and oxygen concentration: implications for cell-based regenerative therapy. Spine (Phila Pa 1976) 41: 743-750.

Naqvi SM, Gansau J, Buckley CT (2018) Priming and cryopreservation of microencapsulated marrow stromal cells as a strategy for intervertebral disc regeneration. Biomed Mater 13: 034106. DOI: 10.1088/1748-605X/aaab7f.

Naqvi SM, Gansau J, Gibbons D, Buckley CT (2019) In vitro co-culture and ex vivo organ culture assessment of primed and cryopreserved stromal cell microcapsules for intervertebral disc regeneration. Eur Cell Mater 37: 134-152.

Noguera R, Nieto OA, Tadeo I, Farinas F, Alvaro T (2012) Extracellular matrix, biotensegrity and tumor microenvironment. An update and overview. Histol Histopathol 27: 693-705.

Noth U, Rackwitz L, Heymer A, Weber M, Baumann B, Steinert A, Schutze N, Jakob F, Eulert J (2007) Chondrogenic differentiation of human mesenchymal stem cells in collagen type I hydrogels. J Biomed Mater Res A 83: 626-635.

Park JB, Chang H, Kim KW (2001) Expression of Fas ligand and apoptosis of disc cells in herniated lumbar disc tissue. Spine (Phila Pa 1976) 26: 618-621.

Pattappa G, Heywood HK, de Bruijn JD, Lee DA (2011) The metabolism of human mesenchymal stem cells during proliferation and differentiation. J Cell Physiol 226: 2562-2570.

Razaq S, Wilkins RJ, Urban JP (2003) The effect of extracellular $\mathrm{pH}$ on matrix turnover by cells of the bovine nucleus pulposus. Eur Spine J 12: 341-349.

Richardson SM, Walker RV, Parker S, Rhodes NP, Hunt JA, Freemont AJ, Hoyland JA (2006) Intervertebral disc cell-mediated mesenchymal stem cell differentiation. Stem cells 24: 707-716.

Riemann A, Ihling A, Schneider B, Gekle M, Thews O (2013) Impact of extracellular acidosis on intracellular $\mathrm{pH}$ control and cell signaling in tumor cells. Adv Exp Med Biol 789: 221-228.

Ringe J, Kaps C, Schmitt B, Buscher K, Bartel J, Smolian H, Schultz O, Burmester GR, Haupl T, Sittinger M (2002) Porcine mesenchymal stem cells. Induction of distinct mesenchymal cell lineages. Cell Tissue Res 307: 321-327.

Roberts S, Evans EH, Kletsas D, Jaffray DC, Eisenstein SM (2006) Senescence in human intervertebral discs. Eur Spine J 15 Suppl 3: S312-316.

Rong C, Chen FH, Jiang S, Hu W, Wu FR, Chen TY, Yuan FL (2012) Inhibition of acid-sensing ion channels by amiloride protects rat articular chondrocytes from acid-induced apoptosis via a mitochondrial-mediated pathway. Cell Biol Int 36: 635-641. 
Roughley PJ (2004) Biology of intervertebral disc aging and degeneration: involvement of the extracellular matrix. Spine (Phila Pa 1976) 29: 26912699.

Selberg J, Jia M, Rolandi M (2019) Proton conductivity of glycosaminoglycans. PLoS One 14: e0202713. DOI: 10.1371/journal.pone.0202713.

Smith LJ, Silverman L, Sakai D, Le Maitre CL, Mauck RL, Malhotra NR, Lotz JC, Buckley CT (2018) Advancing cell therapies for intervertebral disc regeneration from the lab to the clinic: recommendations of the ORS spine section. JOR Spine 1: e1036. DOI: 10.1002/jsp2.1036.

Stoyanov JV, Gantenbein-Ritter B, Bertolo A, Aebli N, Baur M, Alini M, Grad S (2011) Role of hypoxia and growth and differentiation factor- 5 on differentiation of human mesenchymal stem cells towards intervertebral nucleus pulposus-like cells. Eur Cell Mater 21: 533-547.

Thomson BM, Bennett J, Dean V, Triffitt J, Meikle MC, Loveridge N (1993) Preliminary characterization of porcine bone marrow stromal cells: skeletogenic potential, colony-forming activity, and response to dexamethasone, transforming growth factor beta, and basic fibroblast growth factor. J Bone Miner Res 8: 1173-1183.

Vergroesen PP, Kingma I, Emanuel KS, Hoogendoorn RJ, Welting TJ, van Royen BJ, van Dieen JH, Smit TH (2015) Mechanics and biology in intervertebral disc degeneration: a vicious circle. Osteoarthritis Cartilage 23: 1057-1070.

Wei R, Liu S, Zhang S, Min L, Zhu S (2020) Cellular and extracellular components in tumor microenvironment and their application in early diagnosis of cancers. Analytical Cellular Pathology 2020: 6283796. DOI: 10.1155/2020/6283796.

Wuertz K, Godburn K, Iatridis JC (2009) MSC response to $\mathrm{pH}$ levels found in degenerating intervertebral discs. Biochem Biophys Res Commun 379: 824-829.

Yu Y, Chen Z, Li WG, Cao H, Feng EG, Yu F, Liu $\mathrm{H}$, Jiang H, Xu TL (2010) A nonproton ligand sensor in the acid-sensing ion channel. Neuron 68: 61-72.

Yuan FL, Zhao MD, Jiang DL, Jin C, Liu HF, Xu MH, Hu W, Li X (2016) Involvement of acid-sensing ion channel 1a in matrix metabolism of endplate chondrocytes under extracellular acidic conditions through NF-kappaB transcriptional activity. Cell Stress Chaperones 21: 97-104.

Zhang B, Yang S, Sun Z, Zhang Y, Xia T, Xu W, Ye $S$ (2011) Human mesenchymal stem cells induced by growth differentiation factor 5 : an improved selfassembly tissue engineering method for cartilage repair. Tissue Eng Part C Methods 17: 1189-1199.

Zhou R, Wu X, Wang Z, Ge J, Chen F (2015) Interleukin- 6 enhances acid-induced apoptosis via upregulating acid-sensing ion channel 1a expression and function in rat articular chondrocytes. Int Immunopharmacol 29: 748-760.

\section{Discussion with Reviewers}

Reviewer: Could the authors comment on how the specific cell type (BMSCs versus ASCs versus IPSCs) and the specific growth factor used may influence the success of priming? Have the authors considered integrating the mechanical microenvironment of the degenerate IVD into their model? How would this synergise with the biochemical microenvironment to affect stem cell priming?

Authors: The choice of cell type and growth factor supplementation is critical for different aims as this will determine the fate of the individual cell type. With respect to IVD regeneration, a cell type (BMSCs, ASCs, IPSCs or other differentiated cells such as ACs or nasal chondrocytes) that can sustain the harsh conditions typically experienced in the disc is desirable and a growth factor that promotes the deposition of a sGAG and collagen type II-rich ECM is highly favourable. The challenge with the non-homologous use of alternative cell types for disc repair is the regulatory framework and ensuring safety and efficacy. Growth factors from the TGF- $\beta$ superfamily, which includes TGF- $\beta$, BMP and GDF, seem to be particularly suitable for promoting viability and matrix deposition. As the present study highlighted some advantages of using TGF- $\beta 3$ for priming, others have also shown great success using GDF5 and GDF6. A recent review by Hodginson et al. (2020, additional reference) summarises these successes, highlighting the potential for IVD repair and differentiation of MSCs towards an NP-like phenotype. Moreover, NP and AF cells express GDF6 receptors at different degeneration grades and show and increase in NP marker gene expression, such as aggrecan, keratin 18, keratin 19 and forkhead box F1, after GDF6 stimulation, indicating its potential (Hodgkinson et al., 2020, additional reference). However, which growth factor is most efficient in promoting cell survival within the acidic environment is yet to be determined and their effectiveness may be dependent on the cell type or state of differentiation.

Theintegration of themechanicalmicroenvironment to this model would certainly provide a step towards recapitulating in vivo events and further the understanding of the interactions between mechanical and biochemical microenvironments and warrants further investigation.

Yongcan Huang: The acidic microenvironment was able to alter the biology of BMSCs and ACs. Would the activities of the transplanted cells change the situation of the hash degenerated disc microenvironment, making the disc ready for repair or regeneration?

Authors: This is a very interesting question and is important when considering cell-based therapies. It is unlikely that injected cells will improve the biochemical nutrient/acidic microenvironment per se. However, the introduction of BMSCs may have 
a beneficial effect on the inflammatory environment and on the resident NP cell population, which could prove to be important. Also, the metabolic profile of transplanted cells is critical and a low nutrient demand in combination with high matrix deposition would be the most favourable scenario. Hence, if larger cell numbers are injected into the disc to boost the total amount of matrix being deposited, more cells will have to compete for nutrients and the acidity effect, as a result of glycolysis, would likely be exacerbated, compromising the effectiveness of the cell therapy. Computational modelling could potentially be used to help predict these effects and determine the optimal cell number for injection to repair disc tissue without significantly impacting or adversely affecting the local nutrient microenvironment.

\section{Additional Reference}

Hodgkinson T, Gilbert HTJ, Pandya T, Diwan AD, Hoyland JA, Richardson SM (2020) Regenerative response of degenerate human nucleus pulposus cells to GDF6 stimulation. Int J Mol Sci 21: 7143. DOI: 10.3390/ijms21197143.

Editor's note: The Guest Editor responsible for this paper was Zhen Li. 